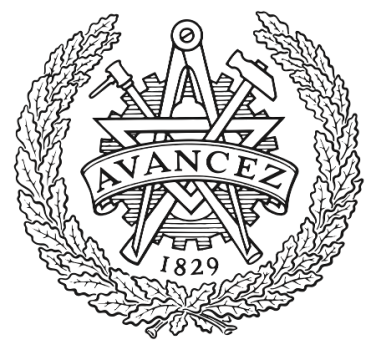

CHALMERS

UNIVERSITY OF TECHNOLOGY

\title{
Excess heat-driven carbon capture at an integrated steel mill - Considerations for capture cost optimization
}

Downloaded from: https://research.chalmers.se, 2023-04-26 08:07 UTC

Citation for the original published paper (version of record):

Biermann, M., Ali, H., Sundqvist, M. et al (2019). Excess heat-driven carbon capture at an integrated steel mill - Considerations for capture cost optimization. International Journal of Greenhouse Gas Control, 91.

http://dx.doi.org/10.1016/j.ijggc.2019.102833

N.B. When citing this work, cite the original published paper. 


\section{Excess Heat-Driven Carbon Capture at an}

2 Integrated Steel Mill - Considerations for Capture

3 Cost Optimization

4

5

6

7

8

9

\section{Authors:}

Maximilian Biermann ${ }^{1 *}$

Hassan Ali ${ }^{2}$

Maria Sundqvist ${ }^{3}$

Mikael Larsson ${ }^{3,4}$

\section{Fredrik Normann ${ }^{1}$}

\section{Filip Johnsson ${ }^{1}$}

Affiliations:

${ }^{1}$ Chalmers University of Technology, SE-412 96 Gothenburg, Sweden

${ }^{2}$ University of South-Eastern Norway, N-3901 Porsgrunn, Norway

${ }^{3}$ Swerim AB, Box 812, SE-971 25 Luleå, Sweden

${ }^{4}$ Luleå University of Technology, SE- 97187 Luleå, Sweden

*Corresponding Author: max.biermann@chalmers.se

Abstract:

Primary steelmaking in blast and basic oxygen furnaces is inherently carbon-intensive. Partial capture, i.e., capturing only a share of the $\mathrm{CO}_{2}$, is discussed as an option to reduce the cost of carbon capture and storage (CCS) and to realize a near-term reduction in emissions from the steel industry. This work presents a techno-economic assessment of partial capture based on amine absorption of $\mathrm{CO}_{2}$. The cost of steam from excess heat is assessed in detail. Using this steam to drive the capture process yields costs of $28-50 € / \mathrm{CO}_{2}$-captured. Capture of $\mathrm{CO}_{2}$ from the blast furnace gas outperforms end-of-pipe capture from the combined-heat-and-power plant or hot stove flue gases onsite by $3-5 € / \mathrm{t} \mathrm{CO}_{2}$-captured. The study shows that partial capture 
driven exclusively by excess heat represents a lower cost for a steel mill owner, estimated in the range of 15-30 €/t $\mathrm{CO}_{2}$-captured, as compared to full capture driven by the combustion of extra fuel. In addition, the full-chain CCS cost (capture, transport and storage) for partial capture is discussed in light of future carbon prices. We conclude that implementation of partial capture in the steel industry in the 2020s is possible and economically viable if policymakers ensure long-term regulation of carbon prices in line with agreed emission reduction targets beyond Year 2030.

Keywords: MEA, steel making, partial capture, CCS, excess heat, cost estimation

Nomenclature:

\begin{tabular}{|c|c|c|c|}
\hline ASU & Air separation unit & $\mathrm{HL}$ & Heat level \\
\hline $\mathrm{BF}$ & Blast furnace & $\mathrm{HRC}$ & Hot rolled coil \\
\hline BFG & Blast furnace gas & HS & Hot stoves \\
\hline Bio-CHP & Biomass-fired CHP plant & ICA & Intercooled absorber \\
\hline $\mathrm{BOF}$ & Basic oxygen furnace gas & MEA & Monoethanolamine \\
\hline BOFG & Basic oxygen furnace gas & MSR & Market Stability Reserve \\
\hline CAPEX & Capital expenditures & NOAK & Nth-of-a-kind \\
\hline CDQ & Coke dry quenching & OPEX & Operational expenditures \\
\hline CHP & Combined heat and power & RSS & Rich solvent splitting \\
\hline COG & Coke oven gas & $c_{\text {carbon }}$ & Carbon price projection, $€ / \mathrm{tCO}_{2}$ \\
\hline DCC & Direct contact cooler & $c_{N A C}$ & Net abatement cost, $€ / \mathrm{tCO}_{2}$ \\
\hline DSG & Dry slag granulation & $c_{\text {power }}$ & Electricity price, $€ / \mathrm{MWh}$ \\
\hline EAC & Equivalent annualized capture cost & $c_{\text {steam }}$ & Cost of steam, $€ /$ tonne steam \\
\hline EDF & Enhanced detailed factor & $c_{t \& s}$ & Transport and storage cost, $€ / t \mathrm{CO}_{2}$ \\
\hline EU ETS & EU emissions trading system & $m_{\text {steam }}$ & Amount of recovered steam, tonne/annum \\
\hline EUA & European Union Allowance & $P_{\text {gain }, \text { BioCHP }}$ & Power generated from bio-CHP, MWh/annum \\
\hline FGHR & Flue gas heat recovery & $P_{\text {loss }, C H P}$ & $\begin{array}{l}\text { Power loss linked to steam supply from CHP to } \\
\text { capture unit(s), MWh/a }\end{array}$ \\
\hline
\end{tabular}


$41 \quad 1 \quad$ Introduction

42 The iron and steel industry emits about $8 \%$ of the global direct $\mathrm{CO}_{2}$ emissions. More than $70 \%$ 43 of the world's steel is produced in blast (BF) and basic oxygen (BOF) furnaces, which rely on fossil fuels for energy and for reducing the iron ore (World Steel Association, 2017). Amine absorption of $\mathrm{CO}_{2}$ is a mature technology for $\mathrm{CO}_{2}$ separation at a technology readiness level of 9 (IChemE Energy Centre, 2018), i.e. commercially available. The technology has therefore been proposed as a means for carbon capture and storage/utilization (CCS or CCU) for nearterm reductions of emission from the steel industry (Eurofer, 2013; Fischedick et al., 2014; Wörtler et al., 2013). Carbon capture from the steel industry is low-cost compared to other industrial sources like petroleum refining (Bains et al., 2017; Leeson et al., 2017) due to high concentrations of $\mathrm{CO}_{2}$ and large flows of off-gases emitted from integrated steel mills (Ho and Wiley, 2016; Leeson et al., 2017). Today, there is one large-scale (capture capacity of $0.8 \mathrm{Mt}$ $\mathrm{CO}_{2}$ ) demonstration plant from steel mill gases in operation - at the direct-reduced iron plant in Abu Dhabi (Global CCS Institute, 2018). There, the $\mathrm{CO}_{2}$ is captured downstream of the shaft reactor, which is powered by syngas, and utilized for enhanced oil recovery.

The coal used in integrated steel mills (BF-BOF route) has multiple purposes, which make it a challenge to achieve deep carbon reduction. Integrated steel mills have several emission points. Yet, partial capture of $\mathrm{CO}_{2}$ from the major stacks, i.e. power plant, hot stoves, coke ovens, sinter plant, and lime kiln, would reduce considerably the site emissions. Studies of capture from these stacks applying $90 \%$ separation rate in the absorber with a $30 \mathrm{wt}$.\% aqueous MEA solvent have estimated a mitigation potential of $50 \%-80 \%$ of all site emissions at an avoidance cost of 60 $100 €_{2015}$ per tonne $\mathrm{CO}_{2}$, depending on how many stacks are included and which assumptions are applied to the energy supply and cost parameters (Arasto et al., 2013; Cormos, 2016; Ho et al., 2013; IEAGHG, 2013; Tsupari et al., 2013). The present work focuses on the stacks with high gas flow and $\mathrm{CO}_{2}$ concentration, and, thus, prospectively, with low capture cost, and adapts the capture rate to match the available excess heat.

In steel mills, it may be beneficial in terms of energy efficiency and process control to separate $\mathrm{CO}_{2}$ from the process gases prior to their combustion, although $>20 \%$ of the carbon is in the form of CO. These process gases include the blast furnace gas (BFG), coke oven gas (COG), and basic oxygen furnace gas (BOFG), all of which are rich in $\mathrm{CO}, \mathrm{H}_{2}$ and $\mathrm{CO}_{2}$. Currently, these gases are combusted for heat generation in the power plant, hot stoves, coke ovens, lime 


\section{Manuscript - Excess Heat-Driven Carbon Capture at an Integrated Steel Mill - Considerations for Capture Cost Optimization}

the gas heating value, decrease the gas volume that needs to be handled, and increase the reducing potential of the gas. $\mathrm{BFG}$ comprises around $70 \%$ of the $\mathrm{CO}_{2}$ site emissions and is typically pressurized to around 2-3 bar; its relatively high $\mathrm{CO}_{2}$ partial pressure makes it especially suitable for carbon capture. Carbon capture from BFG using amine absorption, without modifying the blast furnace to enable top gas recycling, has previously been studied (Dreillard et al., 2017; Ho et al., 2013). These studies have generally concluded that capture from process gases has lower specific capture cost but lower $\mathrm{CO}_{2}$ reduction potential relative to capture from the stacks. Dreillard et al. have shown that the co-absorption of CO by MEA is negligible and that the $\mathrm{CO}_{2} / \mathrm{CO}$ selectivity is high, with a $\mathrm{CO}_{2}$ purity level of $>99.5 \%$ being achieved (Dreillard et al., 2017). In the same study, the absence of oxygen in the BFG was shown to reduce solvent degradation compared to capture from the flue gases. Technoeconomic studies of BFG capture with $30 \mathrm{wt}$ \% MEA have reported 19\%-30\% reduction in site emissions at an avoidance cost of 54-72 $€_{2015}$ per tonne $\mathrm{CO}_{2}$ (Dreillard et al., 2017; Ho et al., 2013; Kim et al., 2015; Kuramochi et al., 2012).

All the studies discussed above have assumed a 90\% separation rate in the absorber and have sought to combine stacks or capture from the largest stacks to achieve an "as-high-as-possible" reduction in emissions. Usually, it is proposed that heat be provided by additional fossil fuel combustion, thereby incurring extra investment, operating costs, and $\mathrm{CO}_{2}$ emissions. This approach, which in our previous work on partial capture for process industry was defined as the full capture approach, seeks to minimize the specific investment cost for carbon capture (Biermann et al., 2018). In contrast, partial capture seeks to reduce the operating cost and, thereby, the overall capture cost, by capturing only a share of the accessible $\mathrm{CO}_{2}$ from a flue gas or process gas. The magnitude of this share is governed by economic factors, such as energy prices and policy-driven requirements. Situations that are potentially amenable to partial capture include, for example, industrial sites that have available, low-value excess heat or have multiple stacks that allow only the most suitable stacks to be targeted for capture. An integrated steel mill typically meets both criteria.

A previous study by the authors (Sundqvist et al., 2018) examined how the excess energy from the steel mill in Luleå, Sweden, that is currently used for district heating, process heat, and electricity production could be extended to drive also partial capture. The heat sources, which ranged from power plant steam (back-pressure operation) to the installation of excess heat recovery units, were mapped, and they allowed for a reduction of up to $43 \%$ in site emissions. It was found that partial capture from BFG gave a lower specific heat demand compared to end- 
Manuscript - Excess Heat-Driven Carbon Capture at an Integrated Steel Mill Considerations for Capture Cost Optimization

106 of-pipe capture from the power plant. Furthermore, the increase in the heating value of BFG due to $\mathrm{CO}_{2}$ removal allowed for re-allocation of the process gases in the steel mill, thereby releasing additional excess heat from certain process units to the capture process.

The present work extends our previous study (Sundqvist et al., 2018) to a techno-economic assessment of partial capture in the iron and steel industry through utilization of excess heat. The work illustrates how the reduction in emissions (capture rate) and the corresponding capture cost are governed by the $\mathrm{CO}_{2}$ source and the level of available excess heat. The emphasis here is on the difference in cost between steam from excess heat and additional combustion. Three suitable $\mathrm{CO}_{2}$ sources, hot stove flue gases, power plant flue gases, and BFG are analyzed for various capture rates and levels of heat supply. Partial capture scenarios are defined and compared with full capture benchmarks from the present study and from the literature. From this we discuss partial capture as a near-term mean option for carbon mitigation for the iron and steel industry. In addition, the time perspective and conditions in terms of carbon pricing for such near-term implementation are presented.

120 The Methods section describes the capture scenarios, process modeling, and cost estimation approaches. The Results section is divided into a technical section on capture performance and a section on economics. The latter highlights the cost of steam and Capital Expenditure (CAPEX) before aggregating both CAPEX and Operational Expenditure (OPEX) into a specific capture cost for different capture rates from the three main $\mathrm{CO}_{2}$ sources in the steel mill. A sensitivity analysis highlights the main capture cost-driving parameters before the entire CCS cost chain (capture, transport and storage cost) is discussed for three carbon price projections. Finally, in the Discussion section, the findings are interpreted and compared to the results from the literature.

\section{Methods}

130 Figure 1 shows the setup and scope of the techno-economic assessment of the ${\mathrm{MEA} \mathrm{CO}_{2}-}^{-}$ absorption unit integrated with an existing steel mill. Established modeling tools for the heat and mass balances of the steel mill and the capture unit are used (Sundqvist et al., 2018). In

133 brief, the steel mill model determines the available excess heat and gas properties, which are

134 used as inputs to the capture model. The capture model determines the achievable level of $\mathrm{CO}_{2}$ 135 capture and the lean gas compositions, which are used to iterate the flue gas flow and process 136 gas composition to the steel mill model. To benchmark against full capture, two scenarios include external heat supply by an additional CHP plant fired with low-grade biomass are 
Manuscript - Excess Heat-Driven Carbon Capture at an Integrated Steel Mill Considerations for Capture Cost Optimization

138 considered. The cost of erecting and operating the capture unit covers the costs for capture, $\mathrm{CO}_{2}$

139 compression, heat supply, and the piping used to connect the $\mathrm{CO}_{2}$-rich gases and steam to the

140 designated capture site locations.

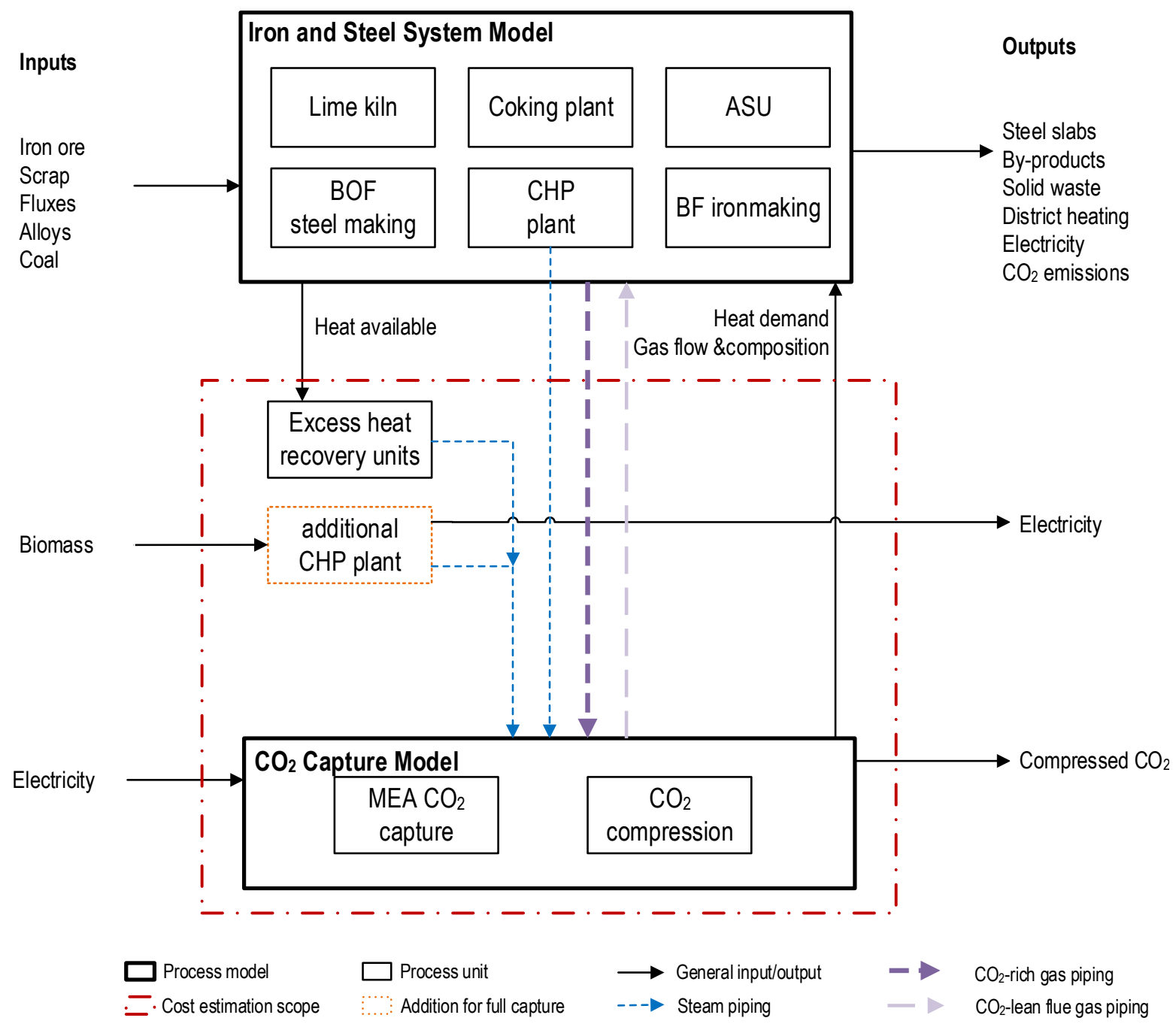

Figure 1: Overview of the methodology applied in the present work. Included are the scope of the steel mill model, the capture unit model, and the techno-economic assessment.

\subsection{Capture scenarios studied}

143 The SSAB site in Luleå has a production rate of around 2.0 Mt of primary slabs per year. In

144 total, the plant site emits around 1.7 tonne $\mathrm{CO}_{2} /$ tonne steel slab produced. The major features

145 of the SSAB plant that distinguish it from other integrated iron and steel plants are that: 1) the

146 blast furnace is only charged with iron ore pellets (no sinter); and 2) downstream treatment of

147 the steel slabs after casting does not take place onsite, but at a separate rolling mill and coating

148 plant. Figure 2 shows the carbon balance of the Luleå site. Carbon is mainly expended for 
Manuscript - Excess Heat-Driven Carbon Capture at an Integrated Steel Mill Considerations for Capture Cost Optimization

149 energy and iron ore reduction and only a small amount is found in the product, $98 \%$ of the carbon is emitted as $\mathrm{CO}_{2}$. In line with the shown carbon balance, this work considers capture from the largest carbon sources, i.e., the blast furnace gas, CHP plant flue gases, and hot stove flue gases. The gas properties of these three $\mathrm{CO}_{2}$ sources are listed in Table 1. The possible heat sources for powering the regeneration of the solvent at $120^{\circ} \mathrm{C}$ are considered in the following order:

155 1) Recovery of excess heat for which no additional direct emissions from combustion arise, and 156 for which only the collection and distribution costs are considered. Table 2 lists five excess heat 157 sources at the Luleå steel mill, as previously identified by the authors (Sundqvist et al., 2018).

158 2) Utilization of available capacity in the existing energy infrastructure. In this case, an augmented boiler capacity is omitted, since the boilers onsite already run at full load throughout 160 the year.

1613 3) Installation of an additional heat supply for which the emissions and costs for the extra 162 primary energy consumption and the required investment are considered. Table 2 includes one 163 additional external heat source in which the level of excess heat is insufficient to meet the 164 capture target in the full capture scenarios

165 Note that the values in Table 2 are given as yearly averages. The order, from top to bottom, 166 represents increased technical implications/decreased accessibility for recovering heat in the form of saturated steam at $3 \mathrm{bar}\left(\sim 133^{\circ} \mathrm{C}\right)$. Note that the amount of assessed heat for each heat source in Table 2 is valid for the Luleå reference mill without $\mathrm{CO}_{2}$ capture. Importantly, Table

1692 also provides the definitions for heat levels 1-6 in the two columns to the right. Starting with 170 the first heat source (HL1), each progressive heat level includes the preceding heat sources, 171 such that the total amount of recovered heat is accumulated, e.g., HL6 implies the utilization of 172 all six heat sources.

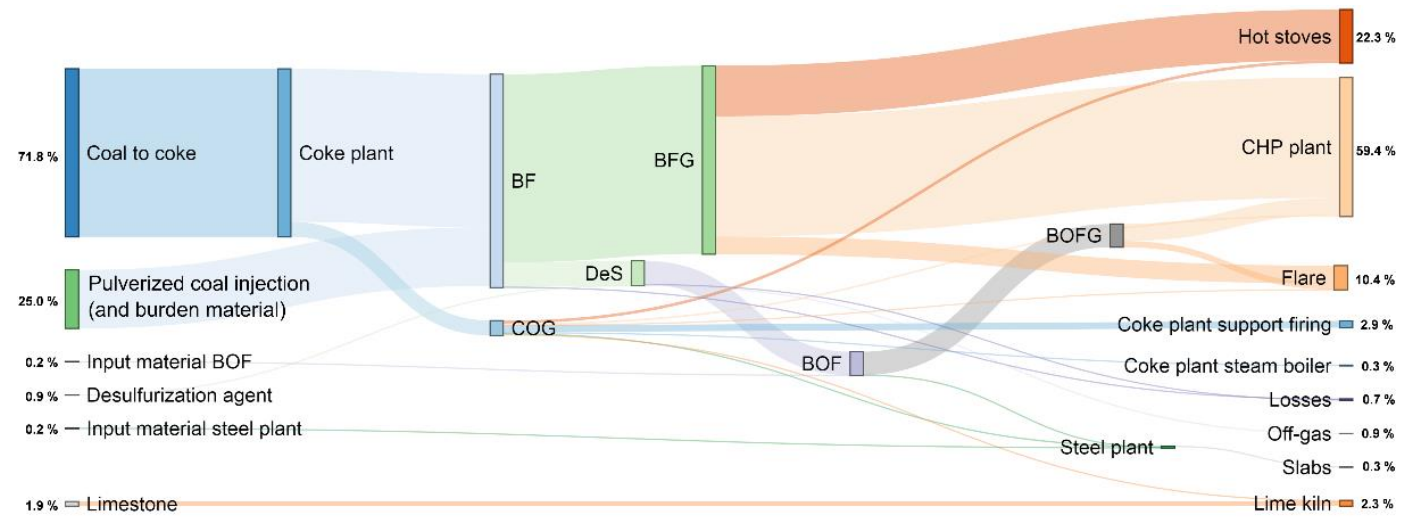


Manuscript - Excess Heat-Driven Carbon Capture at an Integrated Steel Mill Considerations for Capture Cost Optimization

Figure 2: Carbon balance of the Luleå steel mill, as assessed with the iron and steel system model.

173 174

Table 1: Gas properties for the considered $\mathrm{CO}_{2}$ sources at the Luleå steel mill, i.e. in the case without $\mathrm{CO}_{2}$ capture.

\begin{tabular}{llrrr}
\hline & Unit & \multicolumn{2}{c}{$\begin{array}{c}\text { Hot Stoves } \\
\text { flue gas }\end{array}$} & \multicolumn{2}{c}{$\begin{array}{c}\text { CHPG } \\
\text { flue gas }\end{array}$} \\
\hline $\mathrm{CO}_{2}$ & $\mathrm{~mol} \%$ & 25.1 & 24.6 & 29.6 \\
$\mathrm{~N}_{2}$ & $\mathrm{~mol} \%$ & 66.4 & 49.6 & 64.4 \\
$\mathrm{O}_{2}$ & $\mathrm{~mol} \%$ & 1.0 & 0.0 & 0.4 \\
$\mathrm{H}_{2} \mathrm{O}$ & $\mathrm{mol} \%$ & 7.5 & 2.2 & 5.6 \\
$\mathrm{CO}$ & $\mathrm{mol} \%$ & 0.0 & 20.4 & 0.0 \\
$\mathrm{H}_{2}$ & $\mathrm{mol. \%}$ & 0.0 & 3.2 & 0.0 \\
$\mathrm{~T}$ & ${ }^{\circ} \mathrm{C}$ & 269 & 29 & 120 \\
$\mathrm{p}$ & $\mathrm{kPa}$ & 105 & 181.3 & 105 \\
Flow & $\mathrm{kNm} / \mathrm{h}$ & 178.5 & 352.4 & 394.7 \\
\hline
\end{tabular}

175

Table 2: Heat sources for partial capture of $\mathrm{CO}_{2}$ with suitable heat recovery technology, estimated heat recovery

Adapted from (Sundqvist et al., 2018).

\begin{tabular}{|c|c|c|c|c|c|}
\hline Source & Recovery method & $\begin{array}{l}\text { Recovery } \\
\text { efficiency }\end{array}$ & $\begin{array}{c}\text { Heat } \\
(\text { source })^{2} \\
(\mathbf{G J} / \mathbf{h})\end{array}$ & $\begin{array}{c}\text { Accum. } \\
\begin{array}{c}\text { Heat } \\
(\text { level })^{3} \\
(\mathbf{G J} / \mathbf{h})\end{array} \\
\end{array}$ & $\begin{array}{l}\text { Heat } \\
\text { Level } \\
(\text { HL })^{4}\end{array}$ \\
\hline $\begin{array}{l}\text { CHP plant } \\
\text { (excess heat) }\end{array}$ & Back-pressure operation & $63 \%$ & 228.1 & 228.1 & 1 \\
\hline $\begin{array}{l}\text { Gas flaring } \\
\text { (excess heat) }\end{array}$ & Steam boiler & $93 \%$ & 152.8 & 380.9 & 2 \\
\hline $\begin{array}{l}\text { Hot stove flue gas } \\
\text { (excess heat) }\end{array}$ & Heat recovery boiler & $91 \%$ & 32.9 & 413.8 & 3 \\
\hline $\begin{array}{l}\text { Hot coke } \\
\text { (excess heat) }\end{array}$ & $\begin{array}{l}\text { Dry coke quenching }+ \\
\text { heat recovery boiler }\end{array}$ & $67 \%$ & 41.5 & 455.4 & 4 \\
\hline $\begin{array}{l}\text { Hot slag } \\
\text { (excess heat) }\end{array}$ & $\begin{array}{l}\text { Dry slag granulation }+ \\
\text { moving bed heat exchanger } \\
\text { +heat recovery boiler }\end{array}$ & $65 \%$ & 94.2 & 549.5 & 5 \\
\hline $\begin{array}{l}\text { additional CHP plant } \\
\text { (extra primary energy ) }\end{array}$ & $\begin{array}{l}\text { Biomass fired steam boiler }+ \\
\text { back-pressure steam turbine }\end{array}$ & $85 \%{ }^{5}$ & 419.5 & 977.7 & 6 \\
\hline \multicolumn{6}{|c|}{${ }^{1}$ Potential to convert the excess energy into steam. } \\
\hline \multicolumn{6}{|c|}{${ }^{2}$ Accessible energy from specific source at the investigated plant site. } \\
\hline \multicolumn{6}{|c|}{${ }^{3}$ Accumulated accessible energy at the given HL at the investigated plant site. } \\
\hline${ }^{4}$ Rating according to level & accessibility (i.e., technology rea & iness) of the & ss energy. & & \\
\hline
\end{tabular}

185 The present work considers five capture scenarios S1-S5. Each capture scenario includes one 186 or more of the $\mathrm{CO}_{2}$ sources listed in Table 1 and one or more of the identified sources of excess 187 heat or heat levels $(H L)$ from Table 2. Figure 3 presents an overview of the capture scenarios, 
Manuscript - Excess Heat-Driven Carbon Capture at an Integrated Steel Mill Considerations for Capture Cost Optimization

188 showing the integration of the capture units into the steel mill. The considered heat levels that deliver steam to the capture site for each scenario are highlighted in blue. Table 3 summarizes key characteristics of the scenarios. Capture scenarios S1-S3 represent partial capture solely

191 from the hot stove flue gas, BFG, and CHP flue gas, respectively. The heat supply level is based 192 on the available excess heat, which sets the capture rate from the respective $\mathrm{CO}_{2}$ source. In case 193 sufficient amount of heat is available, the capture rate from a single $\mathrm{CO}_{2}$ source is set to a limit 194 of $90 \%$, which resembles full capture and an associated minimum investment cost (Biermann 195 et al., 2018) for enabling capture from that source. Scenarios S4 and S5 represent capture from 196 more than one $\mathrm{CO}_{2}$ source at capture rates of 90\%. In S4 and S5, a biomass-fired CHP plant 197 (Bio-CHP) powers the process in addition to the excess heat. The Bio-CHP plant is a back198 pressure turbine that generates 3 bar of steam for the reboiler of the capture unit. No extra 199 carbon emissions are allocated to the heat and power production from the Bio-CHP. Scenario 200 S4 includes a capture unit with two absorbers and a common stripper, to avoid blending the 201 BFG and hot stove flue gas. Scenario S5 includes a capture unit for the CHP plant flue gases in 202 addition to the unit described in scenario S4. Thus, scenario S5 captures $90 \%$ of the $\mathrm{CO}_{2}$ from 203 all three sources and represents the full capture case in this work, i.e. similar to what was 204 investigated by Ho et al. (Ho et al., 2013).

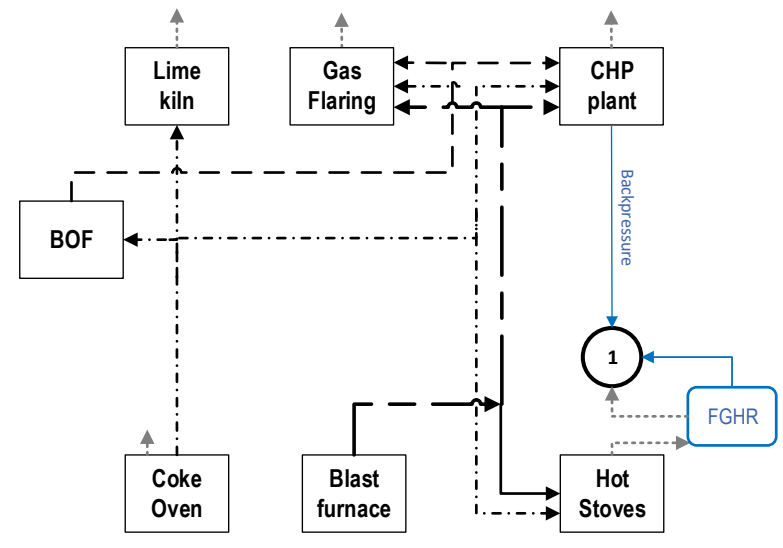

S1

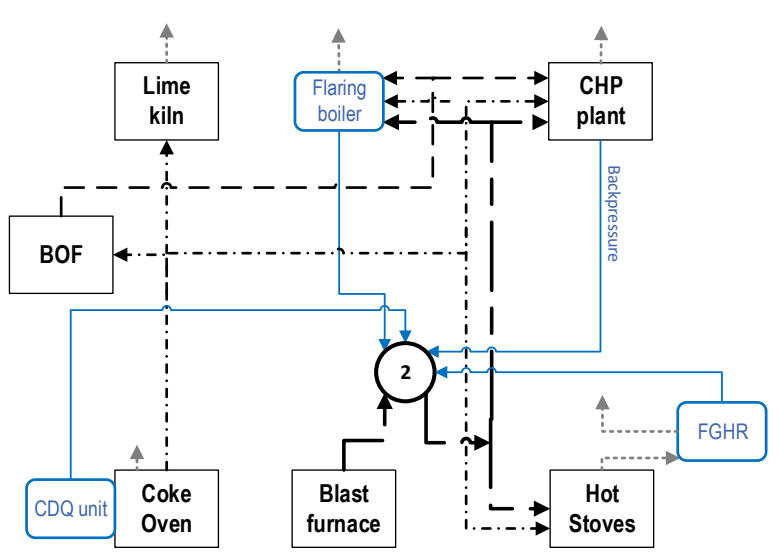

S2 
Manuscript - Excess Heat-Driven Carbon Capture at an Integrated Steel Mill Considerations for Capture Cost Optimization

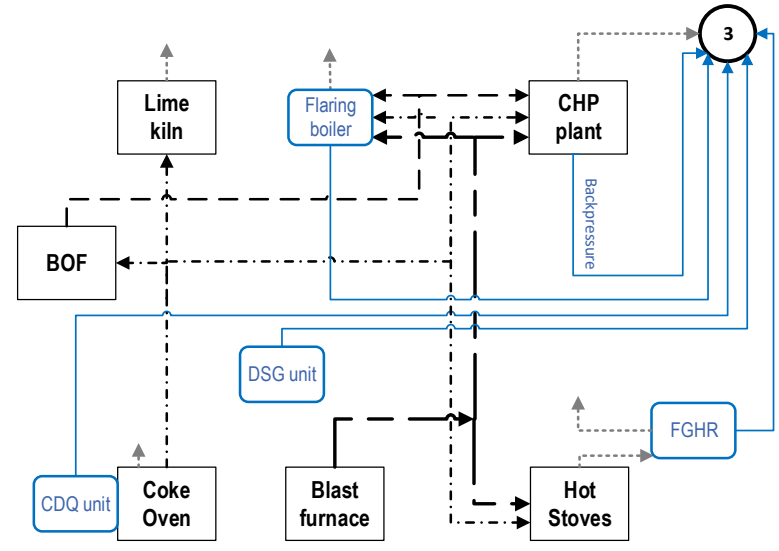

S3

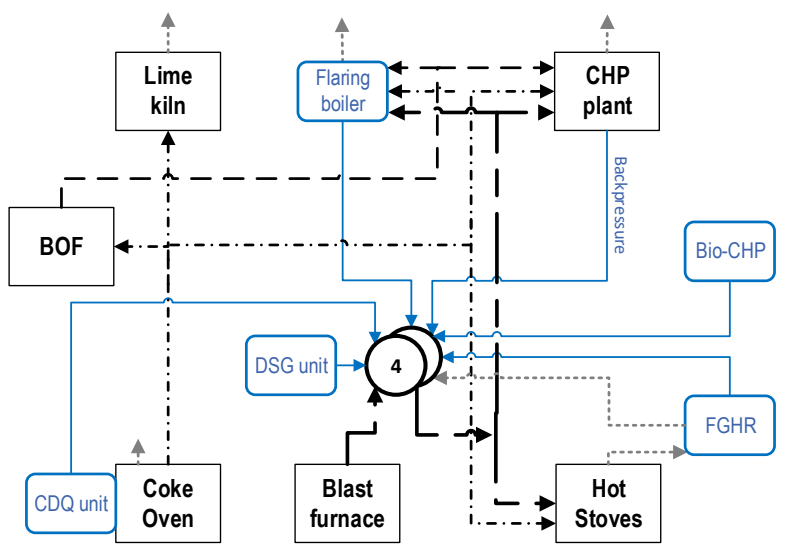

S4
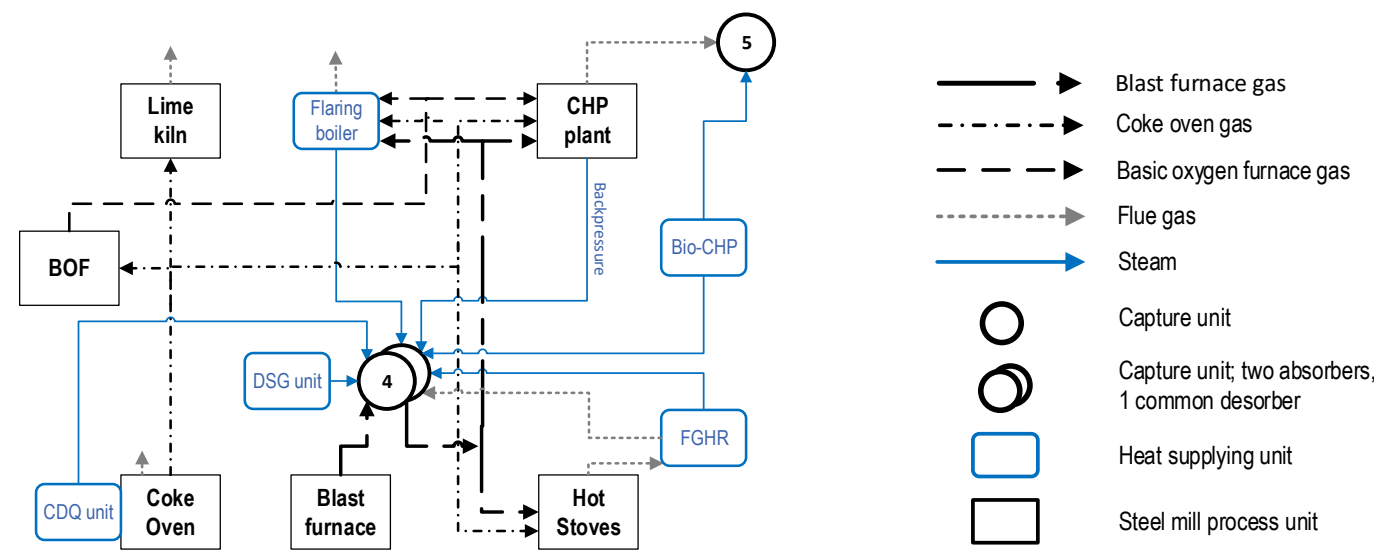

S5

Figure 3: Integration of the heat supplying units (blue) and gas system (black) of the steel mill with the capture unit in scenarios S1-S5. The scenarios consider capture from: S1, hot stove off-gas); S2, blast furnace gas; S3, CHP plant flue gas; S4, hot stoves flue gas plus blast furnace gas; and S5, hot stoves flue gas plus blast furnace gas plus CHP plant flue gas. Circles denote capture units and type of design. Bio-CHP, biomassfired CHP plant; BOF, basic oxygen furnace; CDQ, coke dry quenching; DSG, dry slag granulation; FGHR, flue gas heat recovery from hot stoves.

Table 3: Characteristics of the studied capture scenarios S1-S5. The capture rate depends on the heat that can be made available, only the highest capture rate investigated is shown for each $\mathrm{CO}_{2}$ source. $\mathrm{HL}$, heat level, see Table 2; FGHR, flue gas heat recovery; abs, absorber column; str, stripper column.

\begin{tabular}{llllll}
\hline & S1 & S2 & S3 & S4 & S5 \\
\hline $\mathrm{CO}_{2}$ sources & Hot stoves & BFG & CHP & $\begin{array}{l}\text { BFG, Hot } \\
\text { stoves }\end{array}$ & $\begin{array}{l}\text { BFG, Hot } \\
\text { stoves, CHP }\end{array}$ \\
$\begin{array}{l}\text { Max. capture rate } \\
\text { achieved from source }\end{array}$ & $90 \%$ & $90 \%$ & $76.5 \%$ & $90 \%$ each & $90 \%$ each \\
Heat sources & $\begin{array}{l}\text { FGHR } \\
\text { combined } \\
\text { with } \\
\text { back-pressure } \\
1 /\end{array}$ & HL1-4 & HL1-5 & HL6 & HL6 \\
$\begin{array}{l}\text { 1x abs/1x str } \\
\begin{array}{l}\text { Number of capture units/ } \\
\text { configuration }\end{array}\end{array}$ & 1x abs/1x str & $\begin{array}{l}1 / \\
1 \mathrm{x} \text { abs/1x str }\end{array}$ & $\begin{array}{l}\text { 2x abs/1x str } \\
\text { 2x abs/1x str }\end{array}$ \\
\hline
\end{tabular}




\subsection{Process modeling}

\subsubsection{Iron and steel system model}

212 The integrated iron and steel system is modeled using an in-house, 1-D static model composed 213 of inter-linked mass and energy balances over the process units and includes a detailed model 214 of the blast furnace with accompanying hot stove and burden calculation. Each unit operation

215 (see Figure 1) is described by theoretical correlations and empirical relations from industry data, 216 as described in previous works (Hooey et al., 2010; Sundqvist et al., 2018). The model has 217 previously been used, for example, for integrated steel plant optimization modelling (Hooey et 218 al., 2010) or to assess top gas recycling concepts as part of a techno-economic assessment 219 (IEAGHG, 2013). The model requires calibration to an industrial site and, therefore, should be 220 operated close to the calibration points. In the present study, the model is calibrated against data 221 from the SSAB steel mill in Luleå for the reference year 2006.

\subsection{2 $\mathrm{CO}_{2}$ capture model}

The capture process is assessed using an Aspen Plus model of a $\mathrm{CO}_{2}$ absorption cycle with a 30 wt.\% aqueous MEA solvent, based on the work by Garðarsdóttir et al. (Garðarsdóttir, 2017). Compared to other capture technologies, amine absorption is already commercially available (IChemE Energy Centre, 2018) and suitable for retrofitting (Voldsund et al., 2019). Both these aspects are important to a near-term realization of a partial capture, which is the focus of this paper. The choice of MEA as the amine solvent is based on it being a well-understood benchmark solvent. The likelihood of commercial or advanced solvents economically outperforming MEA adds a conservative perspective to costing results in this work. The model uses rate-based mass transfer correlations and kinetics for MEA reactions. The absorption cycle is designed for partial capture, which means that depending on the gas flow and $\mathrm{CO}_{2}$ concentration, the removal of $\mathrm{CO}_{2}$ from the feed gas will be a function of the available heat (given as a boundary condition, derived from the integrated iron and steel system model). The absorption cycle is optimized to maximize the capture rate by varying the liquid-to-gas ratio $(\mathrm{L} / \mathrm{G})$ through manipulation of the solvent circulation rate. For partial capture from $\mathrm{CO}_{2}$-rich gases, it has been shown that it is more beneficial, in terms of specific reboiler heat demand and therefore possibly costs, to pass the entire process stream through the absorber rather than allow a split-flow of the gas to enter the absorber (Biermann et al., 2018; Øi et al., 2017). 
Manuscript - Excess Heat-Driven Carbon Capture at an Integrated Steel Mill Considerations for Capture Cost Optimization

Two process configurations, illustrated in Figure 4, are used in this work. A single absorber configuration is applied in capture scenarios S1-S3. Due to the proximity of the blast furnace and hot stoves, a double-absorber/common-stripper configuration is used for scenarios S4 and S5. Having an absorber for each gas avoids blending the BFG with the flue gas, which is not desired because the BFG is used as heating gas and a dilution to an even lower heating value is unpractical. A common stripper requires a lower level of investment. Both process configurations use intercooled absorbers (ICA) to enhance absorption, as well as a rich-solvent split (RSS) to augment stripper efficiency, as this reduces the specific reboiler heat demand, and, thus, can lead to lower capture cost (Biermann et al., 2018; Garđarsdóttir et al., 2015; Le Moullec et al., 2014). The modeling setup encompassing rich-split, ICA, and the absorption cycle, together with its key design parameters is described in previous work by the authors

251 (Sundqvist et al., 2018).
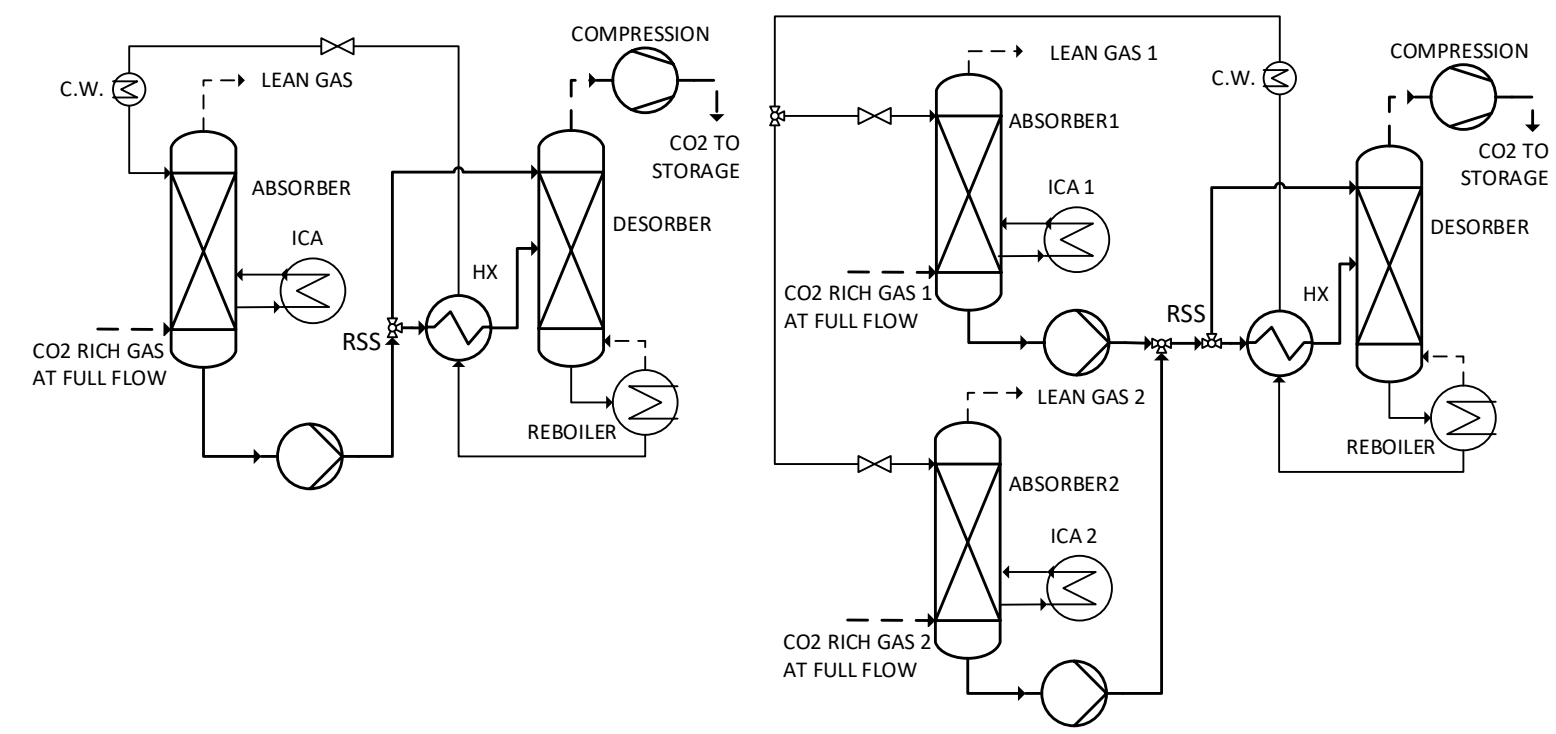

a)

b)

Figure 4: MEA absorption cycle configurations used for partial capture; a) Single absorber configuration. b) Double-absorber/common-stripper configuration;

\subsection{Cost estimations}

254 Cost estimations are performed with the Enhanced Detailed Factor (EDF) method (Ali et al., 255 2019) and are used to discuss the design of the partial capture system for retro-fitting to the 256 Luleå steel mill with the boundary of the cost estimation as shown previously in Figure 1. The costs are aggregated on two levels: 
Manuscript - Excess Heat-Driven Carbon Capture at an Integrated Steel Mill Considerations for Capture Cost Optimization

1) the capture plant cost, i.e., the CAPEX of the capture plant including piping from the $\mathrm{CO}_{2}$ source and all the OPEX related to the capture plant (maintenance, labor, utilities etc.), excluding the steam cost; and

2) the cost of steam, i.e., the CAPEX for piping system required for the steam supply and for the heat recovery equipment, as well as the OPEX related to the equipment and, in particular, any possible changes in power revenue due to excess heat recovery and additional energy supply.

Finally, both the capture plant cost and steam cost are aggregated into an equivalent annualized capture cost (EAC), given in $€$ per captured tonne of $\mathrm{CO}_{2}$ according to Eq. (1). The consideration of integration cost (piping) and steam supply cost is in line with recent developments in costing (van der Spek et al., 2019).

$$
c_{\text {capture,EAC }}=\frac{(C A P E X+O P E X)_{\text {capture plant }}+m_{\text {steam }} \cdot c_{\text {steam }, \text { average }}}{m_{\mathrm{CO}_{2}, \text { captured }}}
$$

The cost estimation is made for high technology maturity and reflects the so-called " $n$ th-of-akind” (NOAK) approach. Using the Aspen In-Plant Cost Estimator, the investment cost for each piece of equipment is estimated and multiplied by an individual installation factor that represents equipment type and size. These installation factors are retrieved from an in-house industry cost database available in the EDF-tool (Ali et al., 2019; Biermann et al., 2018; van der Spek et al., 2017). It is further assumed that all the equipment, except for major vessels such as tanks and columns, is placed in non-insulated buildings. Not included are the cost for purchase of land and piling and the costs for secondary buildings. This method of CAPEX estimation normally constitutes an uncertainty of $\pm 40 \%$ ( $80 \%$ confidence interval). Some of the equipment for heat supply could not be estimated by the individual installation factor method, so cost information from both the academic and grey literature have been used instead, as described in the Appendix in the section on steam cost A.1.2.

Table 4 summarizes the assumptions made regarding the cost estimations. The operational hours represent an annual availability of $95 \%$ for the capture plant and heat recovery equipment, which is motivated by high levels of availability of the blast furnace, hot stoves, and CHP plant. The electricity price is oriented towards the Nordic spot-price market (Nord Pool AS), which in the period 2013-2016 had an average electricity price of $29 € / \mathrm{MWh}$. Electricity required/produced by process units is first balanced within the investigated system shown in Figure 1 before there is purchasing from or selling to the grid. It is assumed that the personnel members operate both the capture plant and the heat supply equipment. The currency 
Manuscript - Excess Heat-Driven Carbon Capture at an Integrated Steel Mill Considerations for Capture Cost Optimization

throughout this study is $€_{2015}$; external input is converted to $€_{2015}$ using Eurostat's consumer price index (Eurostat, 2018) and historical currency exchange rates.

The cost of steam, $c_{\text {steam }}$, for each recovery technology is determined by a bottom-up approach according to Eq.(2) and includes:

- CAPEX for the equipment that converts heat into steam and piping for delivering the steam to the capture site or to connect to the existing network;

- OPEX including the costs for electricity, cooling water, and maintenance, as obtained from mass and energy balances in Aspen Hysys;

- Revenue loss from electricity sales linked to steam supply from the steel mill CHP plant; - Revenue gain from electricity sales linked to the additional biomass-fired CHP.

$$
c_{\text {steam }}=\frac{\left(P_{\text {loss }, \mathrm{CHP}}-P_{\text {gain }, \text { BioCHP }}\right) * C_{\text {power }}+C A P E X+O P E X}{m_{\text {steam }}}
$$

Details of the assumptions made regarding the equipment included to calculate $c_{\text {steam }}$ for each heat level are described in Appendix A.1 in Section A.1.2. Appendix A.1 also decribes the equipment included in the capture plant cost (A.1.1).

In order to investigate the conditions for economic viability of the capture scenarios studied, we calculate the net abatement cost, which is the full-chain CCS cost (capture, transport and storage) related to a carbon price, as calculated in Eq. (3). The net abatement cost represents the remaining cost for the plant owner after receiving credit for the captured carbon, either by capitalizing on not having to buy allowances, or by selling off free allocated allowances on the market. The transport and storage cost, denoted $c_{\mathrm{t} \& \mathrm{~s}}$ in Eq. (3), represent ship transport from the Bothnian Bay to a storage site in the Baltic Sea, and lie within $17-27 € / \mathrm{t} \mathrm{CO}_{2}$ depending on scale (Kjärstad et al., 2016). It should be noted that $\mathrm{CO}_{2}$ storage in the Baltic Sea may not be considered as mature. However, storage in the North Sea may be considered as mature (Gassnova SF, 2019) and the cost estimation by Kjärstad et al. shows that the cost is similar for both options as transport cost only increase slightly with distance, as long as ship-transport is considered (Kjärstad et al., 2016). Three carbon price projections are examined, denoted $c_{\text {carbon }}$ in Eq. (3), as described in Appendix A.1.3.

$$
c_{N A C}=c_{\text {capture,EAC }}+c_{\mathrm{t} \& \mathrm{~S}}-c_{\text {carbon }} \quad\left[€ / t_{\mathrm{CO}_{2}}\right]
$$

Table 4: Economic parameters assumed in this study

Cost year $\quad-\quad$ Year 2015


Manuscript - Excess Heat-Driven Carbon Capture at an Integrated Steel Mill Considerations for Capture Cost Optimization

\begin{tabular}{llr} 
Plant life time & Years & 25 \\
Construction & Years & 2 \\
Rate of return & $\%$ & 7.5 \\
Maintenance & $\%$ inst.cost/annum & 4.0 \\
Plant availability & $\mathrm{h} /$ annum & 8,322 \\
Electricity & $€ / \mathrm{kWh}$ & 0.030 \\
Cooling & $€ / \mathrm{m}^{3}$ & 0.022 \\
MEA & $€ / \mathrm{m}^{3}$ & 1,867 \\
Sludge disposal & $€ / \mathrm{m}^{3}$ & 333.3 \\
Biomass price & $€ / \mathrm{kWh}$ & 0.016 \\
Labor & & 158 \\
\multicolumn{1}{c}{ One engineer } & $\mathrm{k} € /$ annum & 111 \\
\hline
\end{tabular}


Manuscript - Excess Heat-Driven Carbon Capture at an Integrated Steel Mill Considerations for Capture Cost Optimization

3 Results

\subsection{Technical capture performance}

320 This section gives a brief overview of the technical performances of the capture units in the 321 investigated scenarios. Figure 5 shows that the heat requirement for solvent regeneration is 322 dependent upon the $\mathrm{CO}_{2}$ source and achieved capture rate. A general increase in specific heat demand at a higher rate of $\mathrm{CO}_{2}$ removal (lower partial pressure of $\mathrm{CO}_{2}$ in the gas leaving the absorber) is evident. Using MEA absorption, the benefits in terms of heat demand of partial capture are limited to a saving of up to $10 \%$ in required heat per tonne of $\mathrm{CO}_{2}$ captured. Of the three $\mathrm{CO}_{2}$ sources examined, $\mathrm{BFG}$ shows the lowest specific heat demand due to its higher pressure, which results in improved $\mathrm{CO}_{2}$ absorption. Capture from the flue gases of the hot stoves shows a slightly higher heat demand than capture from CHP plant flue gas, which is due to lower concentrations of $\mathrm{CO}_{2}$ in the hot stove flue gas.

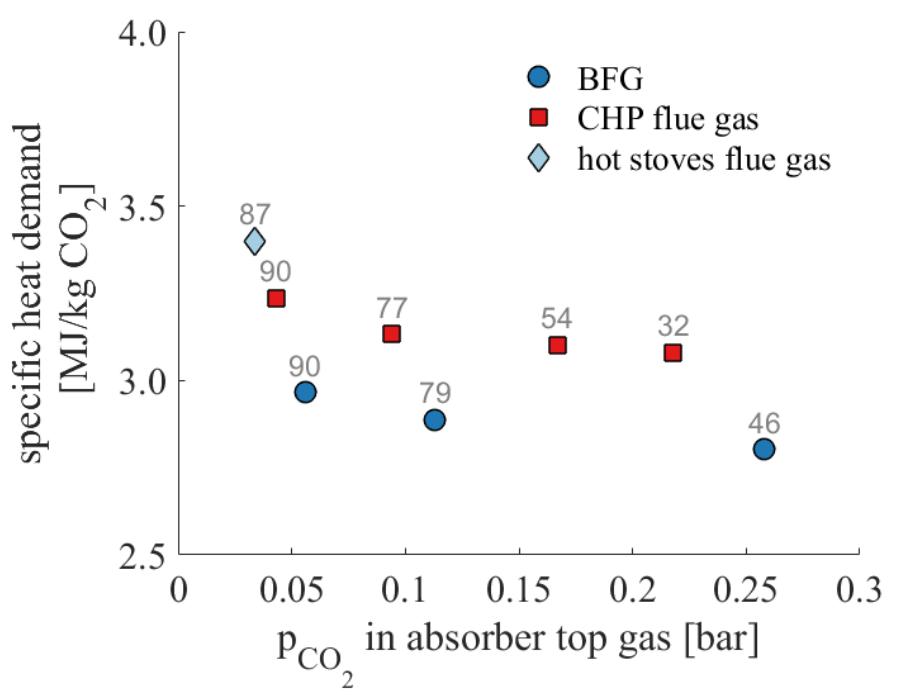

Figure 5: Heat requirement for $\mathrm{CO}_{2}$ separation from BFG, $\mathrm{CHP}$ and hot stove flue gas plotted against partial $\mathrm{CO}_{2}$ pressure in the absorber overhead gas. The numbers in grey show the achieved separation rate of $\mathrm{CO}_{2}$ in the absorber in \%; Note that ordinate does not start from zero.

331 The performance of the system is shown in Table 5 for the five capture scenarios S1-S5 - each at their maximum heat recovery level. The three $\mathrm{CO}_{2}$ sources considered represent almost $85 \%$ of the total site emissions, and full capture from all three sources (S5) yields a total site emission reduction of $76.3 \%$. Full capture from hot stoves alone can mitigate about half as much as full capture from BFG. Utilizing all the retrievable excess heat allows for partial capture of $76 \%$ of the $\mathrm{CO}_{2}$ in the CHP plant flue gases, which corresponds to about $51 \%$ of the total site 
Manuscript - Excess Heat-Driven Carbon Capture at an Integrated Steel Mill Considerations for Capture Cost Optimization

capture, and the system becomes a net importer of electricity from the grid at capture rates $>20$ $22 \%$. The increased electricity demand is predominantly due to the demand for power for $\mathrm{CO}_{2}$ compression and the need to compensate for the loss of electricity production due to backpressure operation. It is noteworthy that capturing from BFG (S2) increases the heating value of the BFG and allows for a process gas re-allocation, i.e. greater usage of BFG in the hot stoves and coke oven gas in the CHP (Sundqvist et al., 2018), unlocking a potential of 2-3 MW of excess heat that can be used for carbon capture compared to the steel mill with no capture. This re-allocation of process gases decreases the energy demand and the system becomes more energy-efficient than the reference case without capture, albeit at the expense of power generation. The net power output improves in S4 and turns positive in S5 with additional fuel input in the form of biomass being supplied to the system.

Table 5: System performance in terms of reduced emissions reduction, power generation, and total energy input for each capture scenario (S1-S5), with the highest level of supplied heat (HL) tested. Ref, No capture; S1, hot stoves; S2, BFG; S3, CHP; S4, BFG + hot stoves; S5, BFG + hot stoves + CHP.

\begin{tabular}{llrrrrrr}
\hline & unit & Ref & S1 & S2 & S3 & S4 & S5 \\
\hline Heat level (highest tested) & & - & HL1m & HL4 & HL5 & HL6 & HL6 \\
Total site reduction & $\% \mathrm{CO}_{2}$ & 0 & 19.0 & 38.8 & 43.2 & 51.0 & 76.3 \\
Specific heat demand & $\mathrm{MJ} / \mathrm{kg} \mathrm{CO}_{2}$ & 0 & 3.40 & 2.90 & 3.12 & 3.04 & 3.15 \\
Heat supplied to reboiler & $\mathrm{GJ} / \mathrm{h}$ & 0 & 262 & 457 & 549 & 629 & 978 \\
Additional biomass input & $\mathrm{GJ} / \mathrm{h}$ & 0 & 0 & 0 & 0 & 113 & 674 \\
Net power output & $\mathrm{GJ} / \mathrm{h}$ & 30 & 4 & -30 & -36 & -25 & 62 \\
Total energy input & $\mathrm{TJ} / \mathrm{h}$ & 6.26 & 6.26 & 6.17 & 6.29 & 6.28 & 6.88 \\
\hline
\end{tabular}

\subsection{Economic efficacy}

First, the CAPEX and the cost of steam are presented separately. Thereafter, the total annualized cost for the Luleå plant case is discussed. The total annualized cost is then analyzed for sensitivity towards selected cost parameters.

\subsubsection{Investment cost of the capture plant}

The installed cost for a capture plant increases with the amount of $\mathrm{CO}_{2}$ captured and, thus, the capture rate. However, due to economy of scale, the specific CAPEX for each tonne of $\mathrm{CO}_{2}$ captured decreases with scale for the captured $\mathrm{CO}_{2}$. Figure 6 shows the magnitudes of these effects on scenarios S1 HL1, S3 HL2 and S2 HL2. The cost break-down highlights the compressor, cross heat exchanger, reboiler, and gas piping as the most expensive items of equipment. The relative proportions of the cost categories vary with scale, $\mathrm{CO}_{2}$ source and plant 
Manuscript - Excess Heat-Driven Carbon Capture at an Integrated Steel Mill Considerations for Capture Cost Optimization

364 design. For instance, the cost of the compressor is merely a function of scale, the gas piping 365 depends highly on the $\mathrm{CO}_{2}$ source, and the separation columns obviously account for a larger 366 share of the cost in the cases designed to include two absorbers and one stripper. A more 367 detailed break-down of installation cost per equipment type is appended in section A.2, Table 368 A.4, in which a partial capture scenario (S2 HL3) is compared with the full capture scenario 369 (S5 HL6).

370 Capture from BFG (S2 HL2) requires an investment that is lower by ca. $3 € /$ tonne $\mathrm{CO}_{2}$ than 371 capture from CHP plant flue gases (S3 HL2). The slightly higher pressure of the BFG allows 372 for smaller diameters of the columns and piping compared with capture from CHP or HS flue 373 gases and this yields a lower CAPEX. Capture from the hot stoves (S4 HL6) or the CHP (S5 374 HL6) in combination with capture from the BFG is relatively inefficient, as BFG is the main 375 fuel feed to the hot stoves and the CHP. The concentration of $\mathrm{CO}_{2}$ drops from $25 \%$ and $30 \%$ to $37617 \%$ in the hot stoves and CHP flue gas, respectively, when $90 \%$ of the $\mathrm{CO}_{2}$ in the $\mathrm{BFG}$ is 377 captured. The lower inlet concentration increases solvent circulation and decreases $\mathrm{CO}_{2}$ 378 loading, causing the equipment to be less cost-effective per tonne of $\mathrm{CO}_{2}$.



Figure 6: Installation cost (diamond) and specific CAPEX (bars with cost categories) of the $\mathrm{CO}_{2}$ capture plant versus captured $\mathrm{CO}_{2}$ for selected capture scenarios 
Manuscript - Excess Heat-Driven Carbon Capture at an Integrated Steel Mill Considerations for Capture Cost Optimization

\subsubsection{Cost of steam supply}

Figure 7 shows the factors governing the cost of steam calculated according to Eq.(2). The cost is primarily determined by the type of heat-recovery technology used (cf. Table 2), the distance to the capture site, and the amount of retrievable steam. A substantial amount of steam, 220 $228 \mathrm{GJ} / \mathrm{h}$ on average, may be obtained by operating in back-pressure mode for the entire operational year at a cost $<2 €$ per tonne of steam. The cost is dominated by the loss in power revenues. The recovery of steam from flare gases generates a cost of $7( \pm 2) € /$ tonne steam, mainly due to the cost of the piping required to lead the flare gases to the additional steam boiler. Heat recovery from hot stove flue gases supplies relatively low levels of steam $(\sim 32$ GJ/h), although at a low cost of $2-4 € /$ tonne. The distinct difference in steam cost for FGHR between capture from BFG (S2) and CHP flue gas (S3) is attributable to the longer piping distance in the CHP scenario. Using coke dry quenching (CDQ) to generate low-pressure steam comes at a relatively high costs of $45-55 € /$ tonne due to the large investment required. Here, the BFG scenario (S2) is more expensive because the steam production is matched to the capture rate cap of $90 \%$, whereas more steam is recovered from excess heat in the CHP flue gas scenario (S3), which captures $64 \%$ of the $\mathrm{CO}_{2}$ at a similar capital expense. Dry slag granulation (DSG) has a comparatively low cost for steam, ca. $5 € /$ tonne, and a higher capacity than CDQ. However, the cost for DSG is uncertain, as it is not a commercial technology. Additional primary energy supply in the form of a biomass-fired CHP plant can generate steam at a cost of $28( \pm 5.1) € /$ tonne and $18( \pm 2.7) € /$ tonne for S4 and S5, respectively. The difference in cost is due to economy of scale. In both scenarios, the costs are dominated by the cost of fuel, although the produced electricity helps to reduce the steam cost by $5-6 € /$ tonne. This also implies that an investment that is solely motivated by power revenues does not pay off. The electricity price would have to be at least $102 € / \mathrm{MWh}$ and $138 € / \mathrm{MWh}$ for S5 and S4, respectively, for the investment to break even.

Figure 8 shows the average steam costs for the successive deployment of the discussed heat recovery technologies, with excess heat recovery being deployed before additional combustion. The increments in steam cost represent the deployment of the next heat-supplying technology with costs (CAPEX and OPEX) at the respective scale of heat supply (in MW). The average steam cost increases from $1( \pm 0.05) € /$ tonne for utilizing only the heat available as backpressure from the existing steam cycle to $12( \pm 2) € /$ tonne for full capture powered by the installation of an additional steam cycle (Bio-CHP). Note that if all the steam were to be generated through a biomass-fired steam boiler the cost of steam would be around 14-30 
Manuscript - Excess Heat-Driven Carbon Capture at an Integrated Steel Mill Considerations for Capture Cost Optimization

$414 € /$ tonne. The average cost of steam is similar for the three $\mathrm{CO}_{2}$ sources in $\mathrm{S} 1-\mathrm{S} 3$, with the 415 differences mainly seen for back-pressure operation and gas flaring. The cost of supplying 416 steam for BFG capture (S2) is higher because the loss of power-related revenue is greater and 417 increases beyond the first heat recovery level (back-pressure). The more heat is retrieved, the 418 more $\mathrm{CO}_{2}$ can be captured and the BFG is upgraded in terms of its heating value, allowing for 419 extended use of BFG in other steel mill units at the expense of electricity generation in the CHP 420 plant (cf. (Sundqvist et al., 2018)).

421

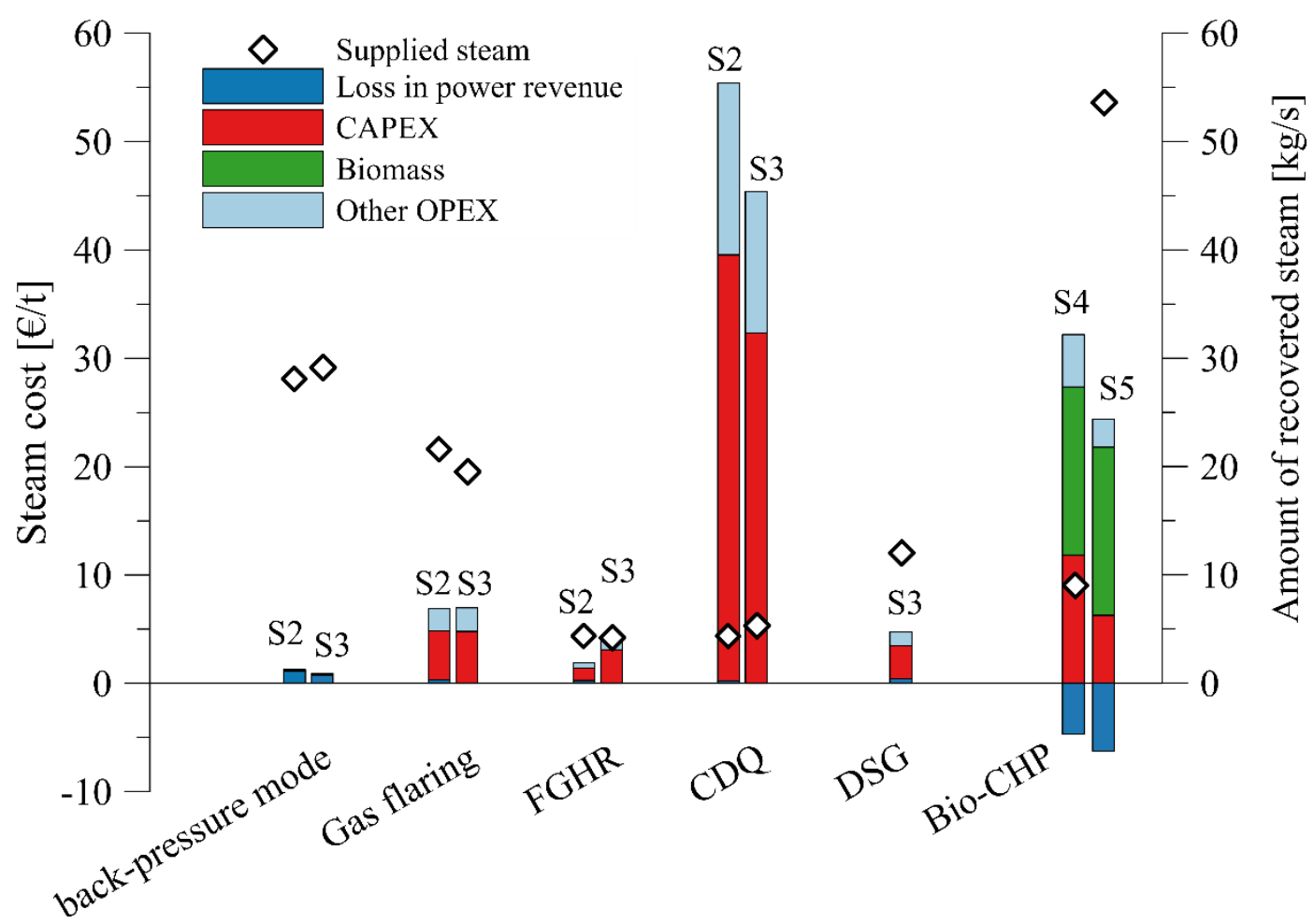

Figure 7: The costs of steam recovered in capture scenarios S2 and S3 via CHP back-pressure operation, gas flaring, flue gas heat recovery (FGHR), coke dry quenching(CDQ), and dry slag granulation (DSG), as compared to the costs of steam produced in additional biomass-fired CHP (Bio-CHP) in capture scenarios S4 and S5. 
Manuscript - Excess Heat-Driven Carbon Capture at an Integrated Steel Mill Considerations for Capture Cost Optimization



Figure 8: Average costs of steam for capture scenarios S1-S5 in relation to the amount of steam available for capture: FGHR, flue gas heat recovery; CDQ, coke dry quenching; DSG, dry slag granulation; Bio-CHP, biomass-fired CHP plant. The parenthesis in the figure represent the recovery technology being implemented successively with increasing steam amount.

3.2.3 Equivalent annualized capture cost

425 The equivalent annualized capture cost (EAC) is aggregated from the capture plant cost and 426 steam cost according to Eq. (1). The annualized absolute cost including CAPEX and OPEX are 427 in the range of $20.6( \pm 4.1) \mathrm{M} €$ to $111.9( \pm 14.8) \mathrm{M} €$ for the smallest and largest annual capture capacities of $0.64 \mathrm{Mt} \mathrm{CO}_{2}$ /annum and $2.58 \mathrm{Mt} \mathrm{CO}_{2}$ /annum, respectively. Figure 9 demonstrates that the capture costs for the studied scenarios vary within the range of 28 $50 € /$ tonne $\mathrm{CO}_{2}$-captured depending on the amount of $\mathrm{CO}_{2}$ captured. A range of low-capture costs is observed for $0.7-1.2 \mathrm{Mt} \mathrm{CO}_{2} /$ annum, corresponding to a $19-36 \%$ reduction in site emissions, after which the capture cost increases with capture rate as more expensive heat recovery equipment is installed. The lowest capture cost of $28( \pm 4) € /$ tonne $\mathrm{CO}_{2}$-captured is observed in scenario S2 HL3, i.e., capture from BFG with heat supplied from back-pressure operation, gas flaring, and flue gas heat recovery (FGHR), achieving a 36\% (ca. 1.2

$436 \mathrm{Mt} \mathrm{CO}_{2}$ /annum) reduction in site emissions. The full capture scenario S5 HL6, i.e., 90\% capture 437 from BFG, hot stoves, and CHP plant flue gases, shows a rather high cost of $43( \pm 6) € /$ tonne $438 \mathrm{CO}_{2}$-captured, although it achieves a reduction in site emissions of $76 \%$ (ca. 2.6 
Manuscript - Excess Heat-Driven Carbon Capture at an Integrated Steel Mill Considerations for Capture Cost Optimization

$439 \mathrm{Mt} \mathrm{CO}_{2}$ /annum). Furthermore, it is clear that capture from BFG is more economic by $3 €$ or $5 €$ 440 per tonne $\mathrm{CO}_{2}$-captured (on average) compared to capture from hot stove or CHP flue gases, 441 respectively, which is within the margin of uncertainty for the cost estimation.

442 Figure 10 shows the cost breakdowns for the most cost-effective BFG capture scenario (S2 443 HL3) and the full capture scenario S5, which have annual costs of $33.6( \pm 5.1) \mathrm{M} €$ and $444111.9( \pm 14.8) \mathrm{M} €$, respectively. In the partial capture scenario, CAPEX makes up one-third of 445 the cost, followed by fixed OPEX (maintenance and labor), and the cost of steam recovered 446 from excess heat. In the full capture scenario, steam generation from both excess heat and 447 additional fuel input is the dominating cost with a share of $39 \%$, followed by CAPEX at $27 \%$.

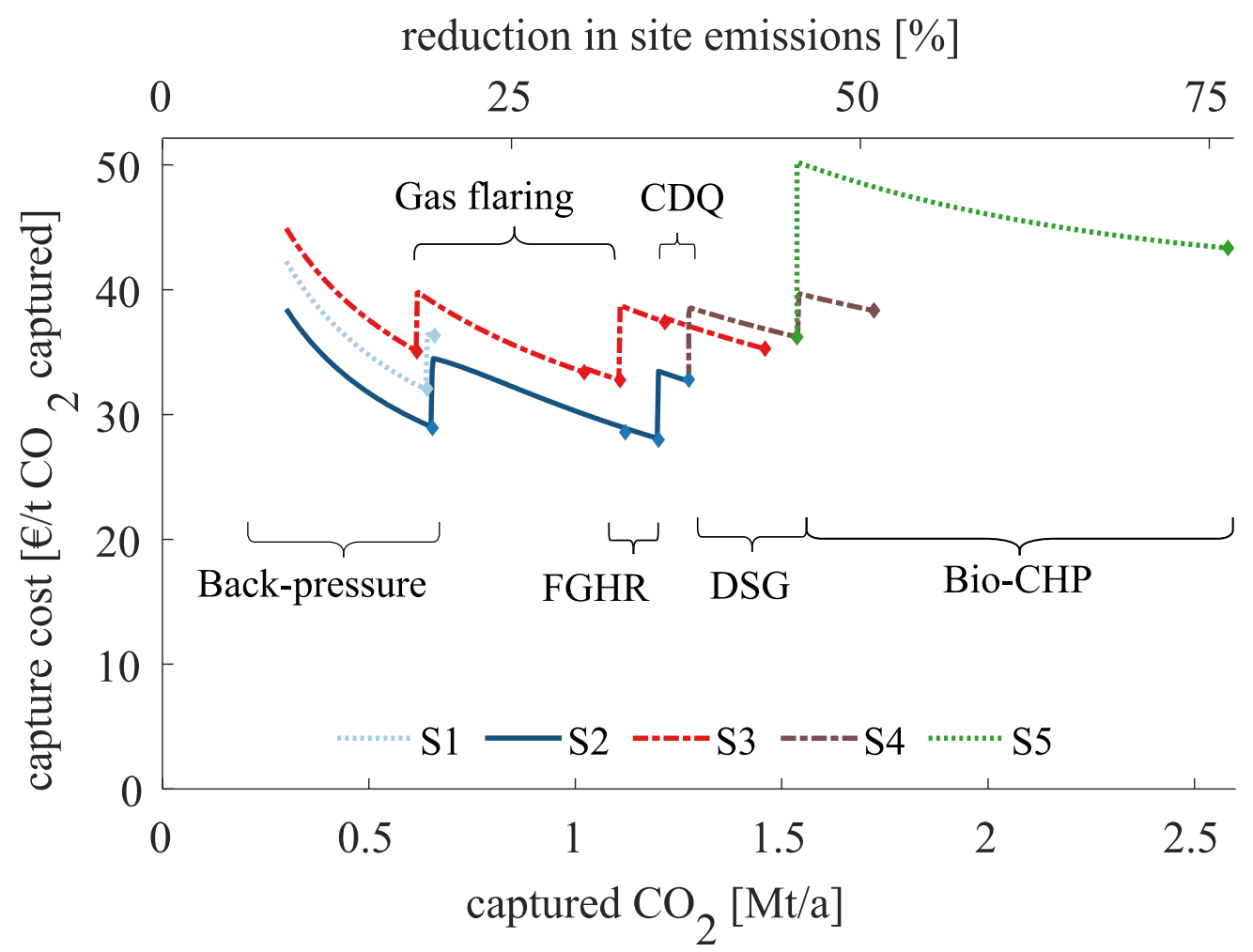

Figure 9: Capture costs for scenarios S1-S5 depending on annually captured $\mathrm{CO}_{2}$ The parentheses and diamonds indicate the successive deployment of heat recovery technologies; FGHR, flue gas heat recovery; CDQ, coke dry quenching; DSG, dry slag granulation; Bio-CHP, biomass-fired CHP plant. 


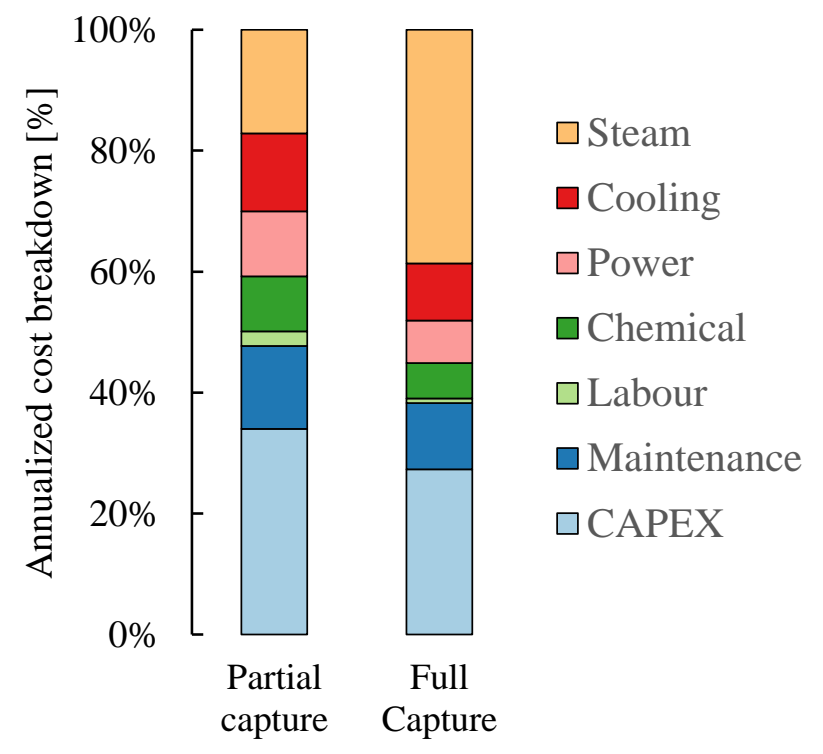

Figure 10: Comparison of the annualized cost breakdowns of the partial capture scenario (S2 HL3) and full capture scenario (S5 HL6). CAPEX represents the capital expenditures for the $\mathrm{CO}_{2}$ capture plant.

\section{$450 \quad 3.2 .4$ Sensitivity analysis}

451 The influences of underlying cost parameters (cf. Table 4) on annualized cost are illustrated in

452 Figure 11 for the partial capture scenario S2 HL3 and the full capture scenario S5 HL6. The

453 listed parameters are altered by $\pm 50 \%$ one at a time. The figure reveals that operational hours,

454 lifetime of the plant, rate of return and external energy (electricity and biomass) are the factors

455 most sensitive to change. Maintenance rate, cooling water supply, and the assumed length of

456 the gas and steam piping influence the cost by <9\%. Overall, the partial capture scenario

457 demonstrates a higher sensitivity than the full capture scenario, as its annual cost is more 458 dependent upon the investment (cf. Figure 10). The exception to this is the cost for external 459 energy, which is more sensitive in the full capture scenario because it relies not only on power 460 imports but also on biomass supply. The electricity price and biomass price are treated as 461 coupled parameters, which is likely to be the case for future electricity systems that rely on 462 renewables with a significant share of biomass (Johansson et al., 2019). Figure 12 shows the 463 net abatement cost, i.e., the full-chain cost for CCS (capture, transport and storage) minus the 464 carbon price, for various carbon and electricity prices over a larger range, and couples the 465 biomass price to the electricity price at a constant ratio for the full capture scenario. In all cases, 466 partial capture is more cost-efficient and less-sensitive to variations in the price of the external 467 energy supply. In general, carbon prices of around 50-60€/tonne $\mathrm{CO}_{2}$ and 50-80€/tonne $\mathrm{CO}_{2}$ 


\section{Manuscript - Excess Heat-Driven Carbon Capture at an Integrated Steel Mill - Considerations for Capture Cost Optimization}

are required for the net abatement cost to become negative for the partial capture scenario and

full capture scenario, respectively.

lifetime partial lifetime full

rate partial rate full

hours* partial hours* full

external energy partial external energy full

maintenance partial maintenance full

cooling partial cooling full

distance piping partial distance piping full

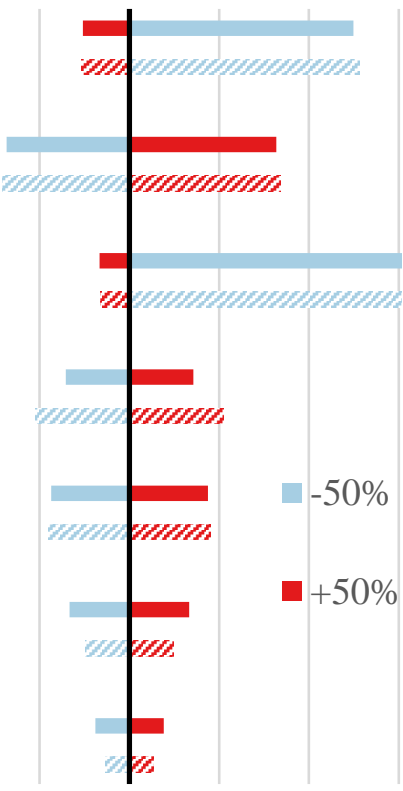

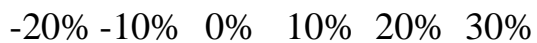

change in capture cost in $\%$

Figure 11: Sensitivity of the annualized capture cost with respect to the main cost parameters for a partial capture scenario (S2 HL3, full bar, base value $28 € /$ tonne $\mathrm{CO}_{2}$ ) and a full capture scenario (S5 HL6, striped bar, base value $43 € /$ tonne $\mathrm{CO}_{2}$ ). * Increase in hours limited to $100 \%$ annual operation, the decrease in hours not shown fully due to scale: cost increase by $67 \%$ and $64 \%$ for partial and full capture scenario, respectively.

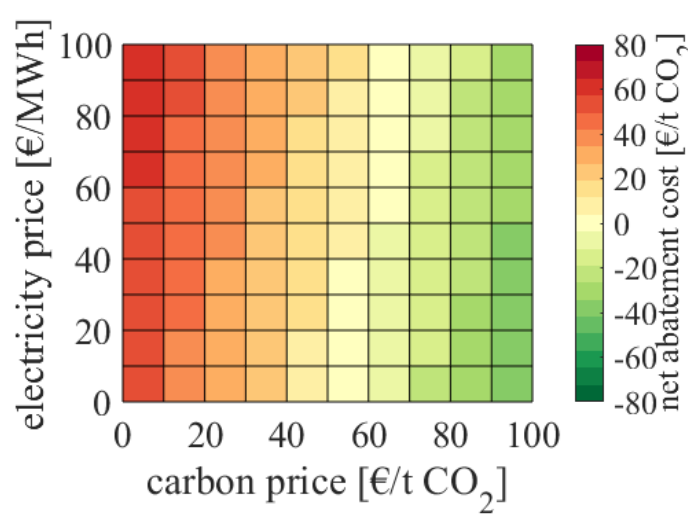

partial capture

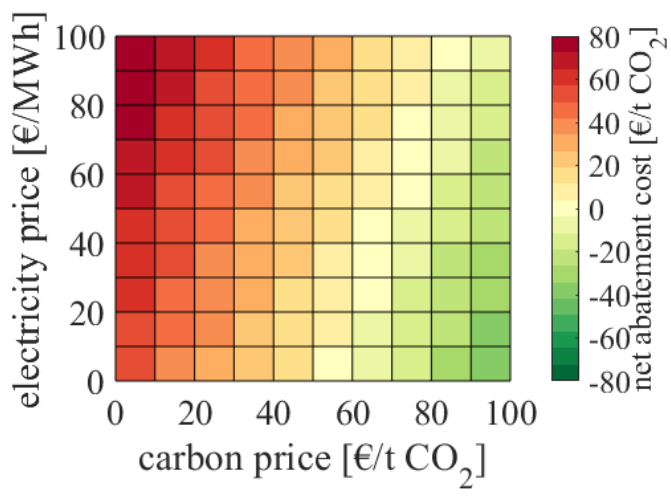

full capture

Figure 12: Sensitivity of the net abatement cost towards the electricity price and carbon price for partial capture (S2 HL3) and full capture (S5 HL6). 
Manuscript - Excess Heat-Driven Carbon Capture at an Integrated Steel Mill Considerations for Capture Cost Optimization

$472 \quad 3.2 .5$ Time perspective on the abatement cost

473 Figure 13 shows the net abatement cost trajectories for partial capture from BFG for the period

474 2018-2040, based on three carbon-pricing projections. $\mathrm{CO}_{2}$ prices for advanced economies in 475 line with IEA's sustainable development scenario (WEO $2{ }^{\circ} \mathrm{C}$ ) would make partial capture at 476 the Luleå steel mill economically viable in Year 2025. Less ambitious policy-driven carbon 477 pricing in the early 2020s will postpone this to Year 2029 (WEO\&NEPP). Following the price 478 projection for the EU ETS by Refinitiv (Qin, 2018), a company providing financial market data,

479 the market does not foresee negative net abatement cost in either the 2020s or in the 2030s when 480 extrapolating the data to the 2030s (see Appendix Table A.3). It should be noted that the applied 481 EU ETS projection does not foresee the carbon price levels necessary to meet the sustainable $482 \quad 2^{\circ} \mathrm{C}$ target (WEO).

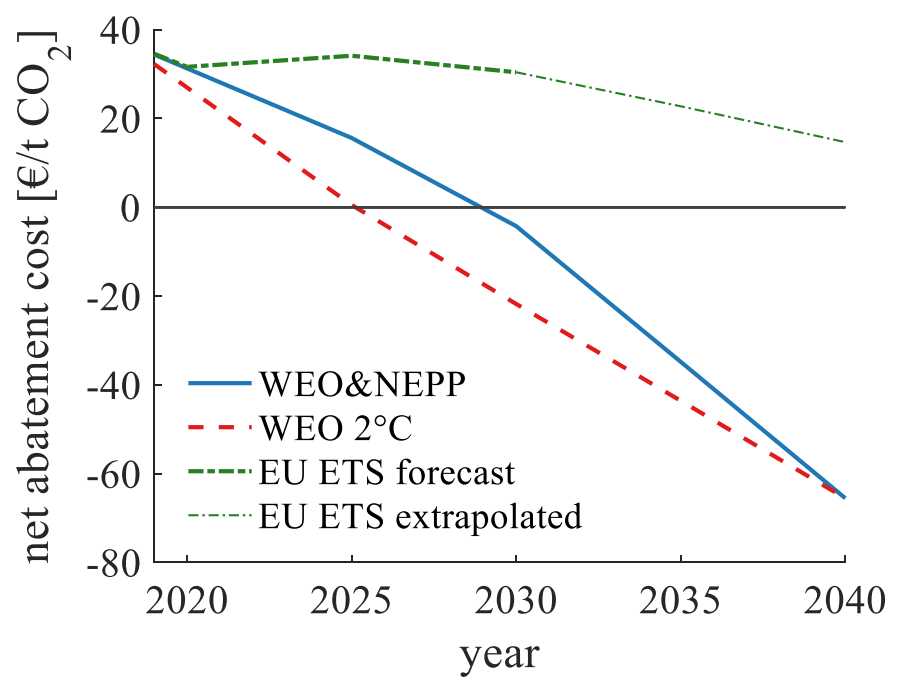

Figure 13: Net abatement costs for the steel industry based on partial capture of $\mathrm{CO}_{2}$ from $\mathrm{BFG}$ (S2 HL3) with excess heat from back-pressure operation, flue gas heat recovery, flare gases, and three carbon price projections: sustainable development projection (WEO $2^{\circ} \mathrm{C}$ ), moderate development projection (WEO \&NEPP), and a carbon-market projection (EU ETS forecast). The carbon price for the EU ETS has been extrapolated for the period 2030-2040. 
Manuscript - Excess Heat-Driven Carbon Capture at an Integrated Steel Mill Considerations for Capture Cost Optimization

484

485

486

487

488

489

490

491

492

493

494

495

496

497

498

499

500

501

502

503

504

505

506

507

508

509

510

511

512

513

514

515

\section{Discussion}

This section is divided into three parts. First, the excess heat sources used for partial capture and their limitations are discussed. Second, the full capture benchmark is compared to the data in the literature and its external heat supply is debated. Third, near-term implementation of partial capture in the iron and steel industry is explored.

\subsection{Limitations on excess heat recovery for partial capture}

The above given techno-economic assessment has found that partial capture with excess heat can be more economic than full capture, provided that low-cost and mature heat recovery technology is implementable. Such technologies include back-pressure operation and flue gas heat recovery, either of which can use the existing infrastructure or relatively low-cost heat recovery units. Flare gas utilization provides steam rather intermittently, and an extra buffer tank may be required to allow continuous heat production, which was not taken into account in the equipment cost. The increase in process complexity is reflected in a higher steam cost from CDQ, though less so for DSG, due to uncertainties in how the costs will turn out once commercialization is achieved.

In all, the excess heat from back-pressure operation and flue gas heat recovery will likely be deployed first, followed by the installation of a new boiler fired by flare gases and additional fuel, e.g., biomass or other. Since steam from CDQ is found to be more expensive than additional combustion (cf. Figure 7), investment in CDQ cannot be motivated based on steam production alone. It should be noted that the steam cost in the present study does not represent secondary effects, such as efficiency gain by capturing from BFG (reduced fuel consumption in the steel mill) or improved quality of the slag due to DSG or avoidance of water pollution and reduction of water consumption due to CDQ. Note that carbon capture and the required heat recovery units are operated continuously at constant load. Martinez Castilla et al. (Martinez Castilla et al., 2019) performed a dynamic modeling study of capture unit operation with seasonal and hourly variations and they found that typical variations are manageable through the implementation of an appropriate capture unit design and control scheme, and that a capture performance close to constant load can be achieved.

\subsection{The full capture benchmark and comparison with the literature}

The comparability of the cost results within the literature is often low due to the high variability of applied methods and scopes. From a literature review on capture cost from the steel industry applying $30 \mathrm{wt} . \%$ aqueous MEA solvents, a cost range for capture from BFG was found to be 
Manuscript - Excess Heat-Driven Carbon Capture at an Integrated Steel Mill Considerations for Capture Cost Optimization

516 54-72 $€ /$ tonne $\mathrm{CO}_{2}$, which is comparable with and even lower than the cost for end-of-pipe 517 capture, which is around 60-100 €/tonne $\mathrm{CO}_{2}$ (see Table A.5 in the Appendix for a list of cost data from the literature reviewed). The techno-economic assessment carried out in the present study confirms that carbon capture from BFG is more cost-effective than end-of-pipe capture from hot stoves or the CHP plant onsite. Compared to the literature, this study concludes that there is a lower cost for full capture, i.e., separating $90 \%$ of the $\mathrm{CO}_{2}$ from $\mathrm{BFG}$, hot stove and CHP plant flue gases, at $43( \pm 6) € /$ tonne $\mathrm{CO}_{2}$ (cf. Figure 9). The reason for this is the use of excess heat to cover $57 \%$ of the heat supply. The supply of heat exclusively from natural gas or coal at a price of 20-22 €/tonne steam (Ali et al., 2018) would entail a cost of 56-58 €/tonne $\mathrm{CO}_{2}$-captured, which is at the lower end of the cost range reported in the literature. Yet, such fossil fuel-based heat supply would increase $\mathrm{CO}_{2}$ emissions, which would also have to be taken into account.

The use of low-grade biomass to provide the remaining $43 \%$ of the required heat for full capture that is not supplied by excess heat, would require roughly 300,000 tonnes (dry) of biomass per year, which is at the scale of the world's largest biomass pelletization plants currently in operation (Kuparinen et al., 2014), so this might pose challenges in terms of production and supply of $\mathrm{CO}_{2}$-neutral biomass. Furthermore, the use of biomass to generate heat for CCS and some electricity may not represent the 'best' option for using a limited resource. Other options even exist in the iron and steel industry for a more-efficient use of biogenic carbon, e.g., as a bio-reductant fed directly to the blast furnace via tuyère injection, thereby replacing pulverized coal injection (Mousa et al., 2016; Wiklund et al., 2017).

4.3 Partial capture and conditions for near-term implementation

In anticipation of the Market Stability Reserve (MSR), the $\mathrm{CO}_{2}$ price in the EU ETS has increased to $>20 € /$ tonne in 2018 after a period of low prices due to oversupply following the financial crisis in Year 2008. The MSR will remove a large share of superfluous emission certificates in the early 2020s, and thus, will likely maintain $\mathrm{CO}_{2}$ price levels at $>20 € /$ tonne (Qin, 2018). Importantly, the capture cost found in this study for partial capture in the steel industry is close to the expected carbon price levels in the near future (Qin, 2018), and thereby cover a large share of the entire full-chain cost. The full-chain cost, including ship transport to the storage site in the Baltic Sea minus a carbon price, i.e. the net abatement cost (cf. Eq. (3)), have been analyzed for different carbon price projections (cf. Figure 13). The market-oriented projection, i.e., the current EU ETS system, is unlikely to trigger the implementation of even a low degree of capture before the Year 2030. Given the strict emission limits foreseen for 
Manuscript - Excess Heat-Driven Carbon Capture at an Integrated Steel Mill Considerations for Capture Cost Optimization

549 Europe, partial capture will not be sufficient for the period 2040-2050, and the economic 550 lifetimes of the capture units will be rather short if implemented in the 2030s or later. However, with policies that assign a higher value to carbon (cf. Figure 13), the economic viability of partial capture looks promising over the entire lifetime of ca. 25 years, starting from the 2020s.

Note that the applied transport and storage costs are quite high, as they account only for the $\mathrm{CO}_{2}$ emissions at a single and rather remote site. Prices closer to $10 € /$ tonne $\mathrm{CO}_{2}$ or lower for less-remote sites or sites connected to a transport hub allowing for pipeline transport (Kjärstad et al., 2016) could result in lower full-chain cost, and, thus, an earlier implementation. It should be noted that the net abatement cost uses electricity price estimates that are based on annual averages and do not cover large price variations in the electricity system, which may be expected in future electricity systems with a large share of renewables (Johansson et al., 2019).

Allocating the cost for $\mathrm{CO}_{2}$ capture, transport, and storage to the steel product (excluding any carbon credit), would lead to an increase in production cost in the range of $20-80 € / \mathrm{t}$ steel (hot rolled coil, HRC) for the investigated scenarios. Relative to an estimated production cost of $466 €_{2015} / \mathrm{t}$ HRC (IEAGHG, 2013), partial capture with excess heat (S2 HL3) and full capture (S5 HL6) would cause an increase in production cost of about $6 \%$ and $17 \%$, respectively. For context, the U.S. tariffs on steel imports were increased by $25 \%$ in 2018 , leading to a turmoil on the global steel market with an increase in HRC prices of about $27 \%$ in the U.S. and a drop by $11 \%$ in Europe within a year (MEPS International Ltd., 2019). Possibly triggered by the more protectionist global trade atmosphere, there have been recent calls for border carbon adjustments (ArcelorMittal, 2018; Mehling et al., 2019), such as a carbon tax for imported goods, which may level competition for domestic manufacturers who face carbon prices and may help incentivize the investment into mitigation technologies, such as CCS. Note that the allocation of CCS cost to the steel product alone is not a priori - costs and reduced $\mathrm{CO}_{2}$ emissions could be allocated to all products including electricity, district/industrial heating, and minerals (slag). The implications of such allocation schemes on the cost and emission intensity of a product-portfolio depend, amongst others, on the choice of mitigation technology and economic conditions, and is a matter of ongoing research.

577 In addition to the uncertainties surrounding economic viability, the long investment cycles in 578 the steel industry may be a decisive factor for the timing of implementation of partial capture. 579 For example, the refractory lining of a blast furnace lasts 15-20 years and it is highly likely that the blast furnace will be used for the entire life time of the lining. Thus, investments made on relining in the period 2020-2030 are likely to be continued until a time of strict carbon 
Manuscript - Excess Heat-Driven Carbon Capture at an Integrated Steel Mill Considerations for Capture Cost Optimization

582 constraints when alternative carbon-free production technologies (e.g. hydrogen reduction) may

583 be a competitive alternative to the blast furnace route.

584 In summary, as a mature and low-cost technology, partial capture of $\mathrm{CO}_{2}$ has a time-window 585 for implementation in the coming 10-15 years (or within one more investment cycle), after 586 which the lifetime of the capture unit will most likely be too short until policies will require 587 close to $100 \%$ decarbonization, which will favor other options for $\mathrm{CO}_{2}$ mitigation from steel 588 manufacturing. However, partial capture could evolve towards full capture over time and 589 achieve low or even near-zero emissions, as required from the power sector to limit warming 590 to $2{ }^{\circ} \mathrm{C}$ (Feron et al., 2019), through onsite technology development, such as solvent 591 improvement, additional capture units, and/or in combination with other measures, such as 592 biomass, electrified heating, and energy efficiency (Biermann et al., 2018). Early 593 implementation of partial capture would initiate large-scale emissions reductions and decrease 594 the risk of other technologies failing to arrive on time and at scale to meet reductions targets. 595 This is an important argument in favor of partial capture since it is the accumulated $\mathrm{CO}_{2}$ 596 emissions which govern if the world will comply with the Paris agreement of staying well below $5972{ }^{\circ} \mathrm{C}$. Thus, unless there are full capture or other zero-emission steel making processes made 598 available economically or technically in the near term, partial capture can constitute a first drastic cut of emissions contributing to significantly lower the accumulated emissions.

\section{Conclusions}

601 A techno-economic assessment of partial capture in primary steelmaking is conducted at the 602 example of a Swedish steel mill. Excess heat from various sources in the steel mill, quantified 603 in a previous work (Sundqvist et al., 2018), is recovered in the form of low-pressure steam to 604 drive a $30 \mathrm{wt} . \%$ amine-based absorption process to separate $\mathrm{CO}_{2}$ from the off-gases of the steel 605 mill. An established cost estimation method is applied together with literature sources to 606 determine the CAPEX and OPEX for the capture unit, the cost of the required gas and steam piping, and the cost for steam production from excess heat.

608 This study finds that for the steel industry, partial capture of $\mathrm{CO}_{2}$ with excess heat is more low609 cost in terms of both the absolute and specifics cost per tonne $\mathrm{CO}_{2}$ than full capture of $\mathrm{CO}_{2}$. The 610 lowest capture cost of $28( \pm 4) €$ per tonne $\mathrm{CO}_{2}$ is found for capture from blast furnace gas with 611 excess heat from the CHP, hot stove flue gas heat recovery and flare gas utilization. This 612 corresponds to a reduction of $36 \%$ in site emissions. The full capture benchmark, i.e., $90 \% \mathrm{CO}_{2}$ 613 separation from three $\mathrm{CO}_{2}$ sources, achieves a reduction of around $76 \%$ at a cost of $43( \pm 6) €$ 
Manuscript - Excess Heat-Driven Carbon Capture at an Integrated Steel Mill Considerations for Capture Cost Optimization

614 per tonne $\mathrm{CO}_{2}$-captured. Full capture relies more on the external energy supply making OPEX 615 the dominating cost factor. Partial capture powered by excess heat is dominated by CAPEX and 616 is less-sensitive to fluctuations in the price of external energy.

617 Capture from the BFG yields a cost which is $3-5 €$ per tonne $\mathrm{CO}_{2}$ lower than end-of-pipe 618 capture from either CHP or hot stoves. This is due to the higher pressure in BFG, which reduces 619 the heat demand and allows for a more cost-efficient design.

620 The bottom-up method applied in this work finds that the cost of steam from excess heat 621 depends on the quantity involved and the recovery technology utilized. Back-pressure 622 operation, heat recovery from hot stove flue gases, and the utilization of flare gases for steam 623 production are available, and implementable heat supply options, with the steam costing $<2 €$, $6242-4 €$, and approximately $7 €$ per tonne of steam, respectively. Retrieving additional excess heat 625 via coke dry quenching or dry slag granulation becomes more expensive and complex. Instead, 626 further heat supply via combustion of additional fuel is likely to yield a lower cost of steam of 627 around $14-28 € / \mathrm{t}$.

628 An analysis relates the full-chain abatement cost for partial capture of $\mathrm{CO}_{2}$ (capture, transport, 629 storage) to different carbon price projections. Early implementation of partial capture of $\mathrm{CO}_{2}$ 630 in the 2020s is possible and economically viable, if policymakers enact and enforce long-term 631 and predictable regulation of carbon prices beyond Year 2030. Over the lifetime of the capture 632 plant, carbon prices will have to be in the range of $40-60 € /$ tonne $\mathrm{CO}_{2}$ on average to justify the 633 investment from the plant owner's perspective.

\section{Notes}

635 The authors declare no competing financial interest.

\section{Acknowledgments}

637 The authors thank Ragnhild Skagestad of SINTEF Industry for her assistance with the cost 638 estimations and David Bellqvist at SSAB for fruitful discussions. The authors thank Vincent 639 Collins in providing language help.

640 This work is part of the $\mathrm{CO}_{2}$ stCap project. The authors thank the research partners The 641 University of South-Eastern Norway, SINTEF Industry (formerly Tel Tek), RISE Bioeconomy, 642 and Swerim AB, as well as the industrial partners: SSAB, GCCSI, IEAGHG, Elkem AS, 643 Norcem Brevik AS, and AGA Gas AB. This work was funded by the Swedish Energy Agency, 644 Gassnova (CLIMIT project no. 248242) and industrial partners. 
646

647

648

649

650

651

652

653

654

655

656

657

658

659

660

661

662

663

664

665

666

667

668

669

670

671

672

673

674

675

676

677

678

679

680

681

682

683

684

685

686

687

Ali, H., Eldrup, N.H., Normann, F., Andersson, V., Skagestad, R., Mathisen, A., Øi, L.E., 2018. Cost estimation of heat recovery networks for utilization of industrial excess heat for carbon dioxide absorption. Int. J. Greenh. Gas Control 74, 219-228. https://doi.org/https://doi.org/10.1016/j.ijggc.2018.05.003

Ali, H., Eldrup, N.H., Normann, F., Skagestad, R., Øi, L.E., 2019. Cost Estimation of CO2 Absorption Plants for CO2 Mitigation - Method and Assumptions. Int. J. Greenh. Gas Control 88, 10-23. https://doi.org/https://doi.org/10.1016/j.ijggc.2019.05.028

Arasto, A., Tsupari, E., Kärki, J., Pisilä, E., Sorsamäki, L., 2013. Post-combustion capture of $\mathrm{CO} 2$ at an integrated steel mill - Part I: Technical concept analysis. Int. J. Greenh. Gas Control 16, 271-277. https://doi.org/10.1016/j.ijggc.2012.08.018

ArcelorMittal, 2018. ArcelorMittal call for green border adjustment to address climate change while securing the competitiveness of European steel mills [WWW Document]. URL https://europe.arcelormittal.com/newsandmedia/pressreleases/PR_Green-borderadjustment (accessed 8.20.19).

Bains, P., Psarras, P., Wilcox, J., 2017. CO2 capture from the industry sector. Prog. Energy Combust. Sci. 63, 146-172. https://doi.org/10.1016/j.pecs.2017.07.001

Biermann, M., Normann, F., Johnsson, F., Skagestad, R., 2018. Partial Carbon Capture by Absorption Cycle for Reduced Specific Capture Cost. Ind. Eng. Chem. Res. 57, acs.iecr.8b02074. https://doi.org/10.1021/acs.iecr.8b02074

Cormos, C.-C., 2016. Evaluation of reactive absorption and adsorption systems for postcombustion $\mathrm{CO} 2$ capture applied to iron and steel industry. Appl. Therm. Eng. 105, 5664. https://doi.org/10.1016/j.applthermaleng.2016.05.149

Dreillard, M., Broutin, P., Briot, P., Huard, T., Lettat, A., 2017. Application of the DMXTM CO2 Capture Process in Steel Industry. Energy Procedia 114, 2573-2589. https://doi.org/https://doi.org/10.1016/j.egypro.2017.03.1415

Eurofer, 2013. A steel roadmap for a low carbon Europe 2050, Eurofer, The European Steel Association. Brussels, http://www.nocarbonnation.net/docs/roadmaps/2013Steel_Roadmap.pdf.

Eurostat, 2018. Harmonised Indices of Consumer Prices (HICP) [WWW Document]. URL http://ec.europa.eu/eurostat/web/hicp (accessed 1.28.19).

Feron, P., Cousins, A., Jiang, K., Zhai, R., Shwe Hla, S., Thiruvenkatachari, R., Burnard, K., 2019. Towards Zero Emissions from Fossil Fuel Power Stations. Int. J. Greenh. Gas Control 87, 188-202. https://doi.org/10.1016/j.ijggc.2019.05.018

Fischedick, M., Marzinkowski, J., Winzer, P., Weigel, M., 2014. Techno-economic evaluation of innovative steel production technologies. J. Clean. Prod. 84, 563-580. https://doi.org/10.1016/j.jclepro.2014.05.063

Garðarsdóttir, S.Ó., 2017. Technical and Economic Conditions for Efficient Implementation of $\mathrm{CO} 2$ Capture - process design and operational strategies for power generation and process industries, Doktorsavhandlingar vid Chalmers Tekniska Högskola. Ny serie, no: 4318. Department of Space, Earth and Environment, Div. Energytechnology, Chalmers University of Technology, Göteborg.

Garđarsdóttir, S.Ó., Normann, F., Andersson, K., Johnsson, F., 2015. Postcombustion CO2 
Manuscript - Excess Heat-Driven Carbon Capture at an Integrated Steel Mill Considerations for Capture Cost Optimization

688

689

690

691

692

693

694

695

696

697

698

699

700

701

702

703

704

705

706

707

708

709

710

711

712

713

714

715

716

717

718

719

720

721

722

723

724

725

726

727

728

729

730

Capture Using Monoethanolamine and Ammonia Solvents: The Influence of CO2 Concentration on Technical Performance. Ind. Eng. Chem. Res. 54, 681-690. https://doi.org/10.1021/ie503852m

Gassnova SF, 2019. Transport and storage: Northern Lights [WWW Document]. URL https://ccsnorway.com/the-project/transport-storage-equinor-shell-and-total (accessed 8.26.19).

Global CCS Institute, 2018. The Global Status of CCS: 2018. Australia.

Haaker, A., 2007. Smurfit Kappa biofuel boiler [in Swedish] - Ökad konkurrenskraft för Smurfit med ny panna [WWW Document]. Bioenergi i skogsindustrin. URL https://www.yumpu.com/sv/document/read/38129232/akad-konkurrenskraft-far-smurfitmed-ny-panna-bioenergitidningen (accessed 8.20.19).

Ho, M.T., Bustamante, A., Wiley, D.E., 2013. Comparison of CO2 capture economics for iron and steel mills. Int. J. Greenh. Gas Control 19, 145-159. https://doi.org/10.1016/j.ijggc.2013.08.003

Ho, M.T., Wiley, D.E., 2016. 28 - Liquid absorbent-based post-combustion CO2 capture in industrial processes, in: Absorption-Based Post-Combustion Capture of Carbon Dioxide. pp. 711-756. https://doi.org/10.1016/B978-0-08-100514-9.00028-7

Hooey, P.L., Bodén, A., Wang, C., Grip, C.-E., Jansson, B., 2010. Design and Application of a Spreadsheet-based Model of the Blast Furnace Factory. ISIJ Int. 50, 924-930. https://doi.org/10.2355/isijinternational.50.924

IChemE Energy Centre, 2018. A Chemical Engineering Perspective on the Challenges and Opportunities of Delivering Carbon Capture and Storage at Commercial Scale.

IEA, 2018. World Energy Outlook.

IEAGHG, 2013. Iron and Steel CCS study (Techno-economics integrated steel mill). 2013/04, July.

Johansson, V., Lehtveer, M., Göransson, L., 2019. Biomass in the electricity system: A complement to variable renewables or a source of negative emissions? Energy 168, 532541. https://doi.org/https://doi.org/10.1016/j.energy.2018.11.112

Kim, H., Lee, J., Lee, S., Lee, I.-B., Park, J., Han, J., 2015. Economic process design for separation of $\mathrm{CO} 2$ from the off-gas in ironmaking and steelmaking plants. Energy 88, 756764. https://doi.org/https://doi.org/10.1016/j.energy.2015.05.093

Kjärstad, J., Skagestad, R., Eldrup, N.H., Johnsson, F., 2016. Ship transport-A low cost and low risk CO2 transport option in the Nordic countries. Int. J. Greenh. Gas Control 54, 168184. https://doi.org/https://doi.org/10.1016/j.ijggc.2016.08.024

Kuparinen, K., Heinimö, J., Vakkilainen, E., 2014. World's largest biofuel and pellet plants geographic distribution, capacity share, and feedstock supply. Biofuels, Bioprod. Biorefining 8, 747-754. https://doi.org/10.1002/bbb.1516

Kuramochi, T., Ramírez, A., Turkenburg, W., Faaij, A., 2012. Comparative assessment of CO2 capture technologies for carbon-intensive industrial processes. Prog. Energy Combust. Sci. 38, 87-112. https://doi.org/10.1016/j.pecs.2011.05.001

Le Moullec, Y., Neveux, T., Al Azki, A., Chikukwa, A., Hoff, K.A., 2014. Process modifications for solvent-based post-combustion CO2 capture. Int. J. Greenh. Gas Control 31, 96-112. https://doi.org/10.1016/j.ijggc.2014.09.024 
Manuscript - Excess Heat-Driven Carbon Capture at an Integrated Steel Mill Considerations for Capture Cost Optimization

Leeson, D., Fennell, P., Shah, N., Petit, C., Mac Dowell, N., 2017. A Techno-economic analysis and systematic review of carbon capture and storage (CCS) applied to the iron and steel, cement, oil refining and pulp and paper industries. Int. J. Greenh. Gas Control In press, 71-84. https://doi.org/10.1016/j.ijggc.2017.03.020

Martinez Castilla, G., Biermann, M., Montañés, R.M., Normann, F., Johnsson, F., 2019. Integrating carbon capture into an industrial combined-heat-and-power plant: performance with hourly and seasonal load changes. Int. J. Greenh. Gas Control 82, 192-203. https://doi.org/https://doi.org/10.1016/j.ijggc.2019.01.015

Mehling, M.A., Van Asselt, H., Das, K., Droege, S., Verkuijl, C., 2019. Designing Border Carbon Adjustments for Enhanced Climate Action, American Journal of International Law. https://doi.org/10.1017/ajil.2019.22

MEPS International Ltd., 2019. World steel prices - Hot rolled coil average prices April 2018 March 2019 [WWW Document]. URL https://worldsteelprices.com/ (accessed 8.19.19).

Mousa, E., Wang, C., Riesbeck, J., Larsson, M., 2016. Biomass applications in iron and steel industry: An overview of challenges and opportunities. Renew. Sustain. Energy Rev. 65, 1247-1266. https://doi.org/10.1016/j.rser.2016.07.061

NEPP, 2019. North European Energy Perspectives Project - Resultat [in Swedish] [WWW Document]. URL http://www.nepp.se/resultat.htm (accessed 1.30.19).

Norgate, T.E., Xie, D., Jahanshahi, S., 2012. Technical and economic evaluation of slag dry granulation, in: AISTech - Iron and Steel Technology Conference Proceedings. pp. 35-46.

Øi, L.E., Sundbø, E., Ali, H., 2017. Simulation and Economic Optimization of Vapour Recompression Configuration for Partial CO2 capture, in: Proceedings of the 58th Conference on Simulation and Modelling (SIMS 58) Reykjavik, Iceland, September 25th - 27th, 2017. Linköping University Electronic Press, Linköpings universitet, Department of and Process, Energy and Environmental Technology, University College of Southeast, Porsgrunn Norway, pp. 298-303. https://doi.org/10.3384/ecp17138298

Qin, Y., 2018. Carbon 2018 - A new story? [WWW Document]. Naturvårdsverket EU ETS Semin. REFINITIV. URL http://www.utslappshandel.se/upload/utslappshandel/dokumentation/20181106/2-carbon2018-a-new-story-refinitiv-20181106.pdf (accessed 2.4.19).

Rydén, B., Unger, T., 2018. [in Swedish] Två NEPP scenarier [WWW Document]. North Eur. Energy Perspect. Proj. URL http://www.nepp.se/pdf/nepp_scenarier.pdf (accessed 2.3.19).

SSAB EMEA AB, 2012. Internal SSAB report [in Swedish]- Prövotids utredning U6 Energiutrredning.

Sundqvist, M., Biermann, M., Normann, F., Larsson, M., Nilsson, L., 2018. Evaluation of low and high level integration options for carbon capture at an integrated iron and steel mill. Int. J. Greenh. Gas Control. https://doi.org/10.1016/j.ijggc.2018.07.008

Tsupari, E., Kärki, J., Arasto, A., Pisilä, E., 2013. Post-combustion capture of CO2 at an integrated steel mill - Part II: Economic feasibility. Int. J. Greenh. Gas Control 16, 278286. https://doi.org/10.1016/j.ijggc.2012.08.017

U.S. DOE Energy Efficiency \& Renewable Energy, 2016. Combined Heat and Power Technology Fact Sheet Series Steam Turbines. DOE/EE-1334 1-4.

van der Spek, M., Roussanaly, S., Rubin, E.S., 2019. Best practices and recent advances in CCS 
Manuscript - Excess Heat-Driven Carbon Capture at an Integrated Steel Mill Considerations for Capture Cost Optimization

99

800

cost engineering and economic analysis. Int. J. Greenh. Gas Control 83, 91-104. https://doi.org/https://doi.org/10.1016/j.ijggc.2019.02.006

van der Spek, M., Sanchez Fernandez, E., Eldrup, N.H., Skagestad, R., Ramirez, A., Faaij, A., 2017. Unravelling uncertainty and variability in early stage techno-economic assessments of carbon capture technologies. Int. J. Greenh. Gas Control 56, 221-236. https://doi.org/10.1016/j.ijggc.2016.11.021

Voldsund, M., Gardarsdottir, S., De Lena, E., Pérez-Calvo, J.-F., Jamali, A., Berstad, D., Fu, C., Romano, M., Roussanaly, S., Anantharaman, R., Hoppe, H., Sutter, D., Mazzotti, M., Gazzani, M., Cinti, G., Jordal, K., Voldsund, M., Gardarsdottir, S.O., De Lena, E., PérezCalvo, J.-F., Jamali, A., Berstad, D., Fu, C., Romano, M., Roussanaly, S., Anantharaman, R., Hoppe, H., Sutter, D., Mazzotti, M., Gazzani, M., Cinti, G., Jordal, K., 2019. Comparison of Technologies for $\mathrm{CO} 2$ Capture from Cement Production-Part 1: Technical Evaluation. Energies 12, 559. https://doi.org/10.3390/en12030559

Wiklund, C.M., Helle, M., Kohl, T., Järvinen, M., Saxén, H., 2017. Feasibility study of woodybiomass use in a steel plant through process integration. J. Clean. Prod. 142, 4127-4141. https://doi.org/10.1016/j.jclepro.2016.09.210

World Steel Association, 2017. Steel Statistical Yearbook 2017. https://doi.org/http://www.worldsteel.org/statistics/statistics-archive/yearbookarchive.html

Wörtler, M., Dahlmann, P., Schuler, F., Lüngen, H.B., Voigt, N., Ghenda, J., Schmidt, T., 2013. Steel' s contribution to a low-carbon Europe 2050 - Technical and economic analysis of the sector's CO2 abatement potential. The Boston Consulting Group, Steel Institue VDEh.

(1) 
Manuscript - Excess Heat-Driven Carbon Capture at an Integrated Steel Mill Considerations for Capture Cost Optimization

801 Appendix

802 A.1 Detailed cost estimation

803 The following sections, which are an extension to Section 2.3, describe in detail the assumptions

804 made and the calculation of the capture plant cost, steam cost, and net abatement cost.

805 A.1.1 Capture plant cost

806 The individual installation factor method described in Section 2.3 is applied to estimate the

807 installation costs for the equipment of the MEA capture plant. Figure A.1 depicts the most

808 relevant items of equipment considered for a single-absorber configuration with gas treatment.

809 The double-absorber/common-stripper configuration (not shown) is identical but includes

810 additional gas treatment, an absorber and washer column, an intercooling arrangement, a rich

811 pump, and a lean cooler. Importantly, the direct contact cooler (DCC) is omitted for the blast

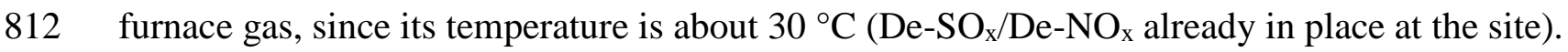

813 Note that gas piping from the $\mathrm{CO}_{2}$ source to the capture plant is considered as item of

814 equipment. The cost of piping installation includes basic fittings, valves and insulation and is

815 based on the site-derived distances for the capture scenarios listed in Table A.1, the gas

816 properties and flow in Table 1, an assumed gas velocity of $40 \mathrm{~m} / \mathrm{s}$, and the piping material (SS-

817 316L). 
Manuscript - Excess Heat-Driven Carbon Capture at an Integrated Steel Mill Considerations for Capture Cost Optimization

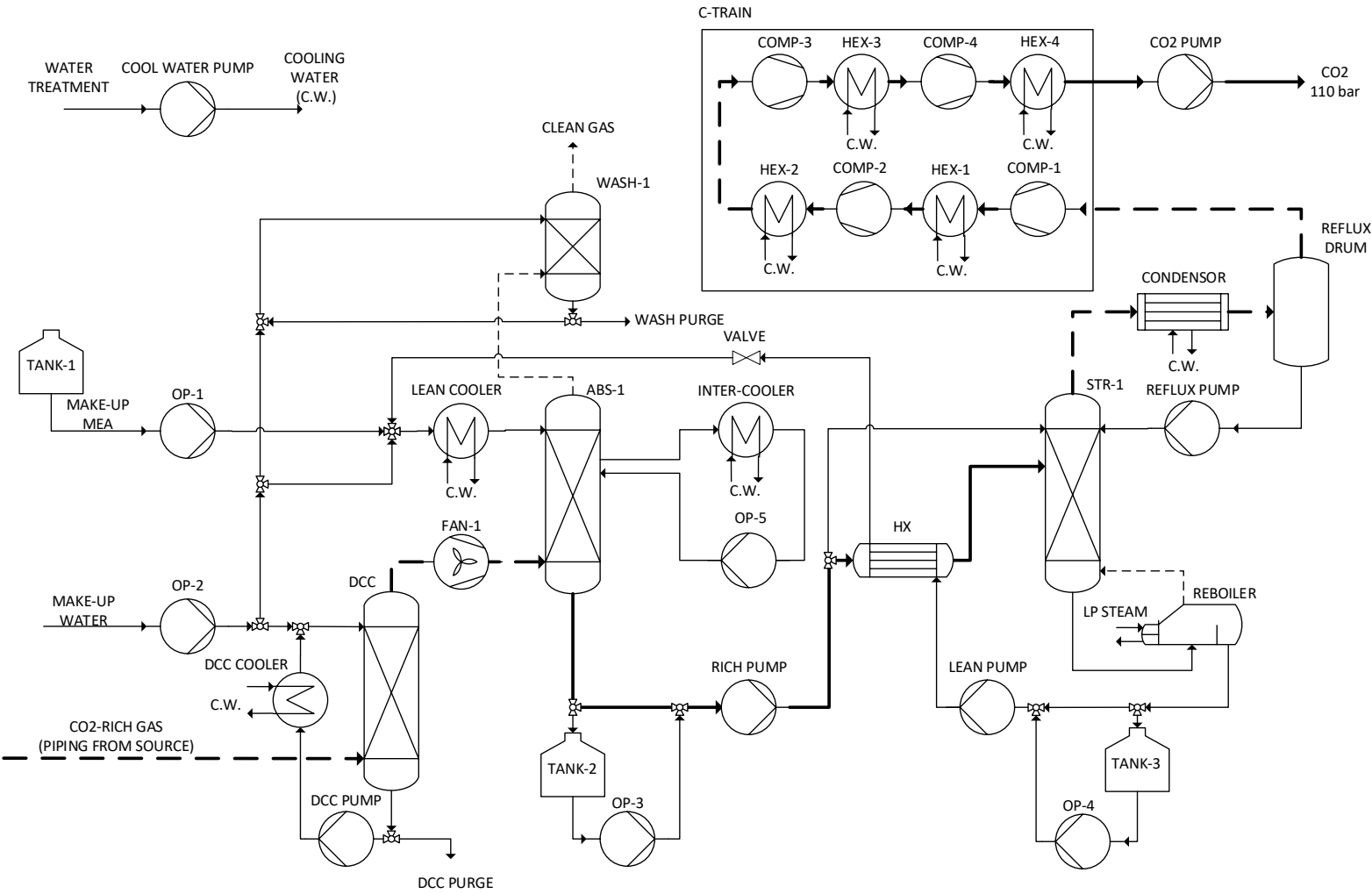

Figure A.1: Major items of equipment included in the installation cost estimation for the capture plant. Shown is an exemplary flowsheet for a single-absorber design with gas piping and gas treatment (DCC) and CO. compression to 110 bar.

Table A.1: Lengths of gas piping considered in capture scenarios S1-S5

\begin{tabular}{llllll}
$\begin{array}{llll}\text { Capture } \\
\text { scenario }\end{array}$ & S1 & S2 & S3 & S4 & S5 \\
& HS & BFG & CHP & BFG+HS & BFG+HS+CHP \\
\hline Length $(\mathrm{m})$ & 50 & 100 & 75 & 175 & 225
\end{tabular}

\section{A.1.2 Cost parameters for heat recovery equipment}

826 The items of equipment considered at each heat level are listed in Table A.2. Steam from turbine 827 back-pressure operation does not require any recovery equipment. For gas flaring, FGHR, and 828 DSG, the cost methodology for heat recovery networks described previously (Ali et al., 2018) 829 is followed. For gas flaring, additional gas piping is required to connect the flare gases to a new 830 steam boiler site. The cost for CDQ and the additional CHP plant is based on external sources. 831 The scaling factor to obtain adjusted installation costs with the power law is 0.65 . For CDQ, 832 the capacity was is to 80 tonnes of coke/h. For DSG, the annual slag production at the site from 833 both the blast furnace and basic oxygen furnace is assumed to be 550,000 tonnes. For the Bio- 
Manuscript - Excess Heat-Driven Carbon Capture at an Integrated Steel Mill Considerations for Capture Cost Optimization

$834 \mathrm{CHP}$, the thermal capacity is set to match the amount of heat required to meet the full capture 835 requirement in scenarios S4 and S5. If more than one heat recovery option is utilized, the steam 836 cost is based on the average cost $c_{\text {steam,average }}$.

837 Table A.2: Assumptions made regarding the cost parameters for the heat-supplying equipment.

\begin{tabular}{|c|c|c|c|c|c|c|}
\hline & Heat recor & & & & & Extra energy \\
\hline Heat source & $\begin{array}{l}\text { Back- } \\
\text { pressure } \\
\text { operation }\end{array}$ & $\begin{array}{l}\text { Gas } \\
\text { flaring }\end{array}$ & $\begin{array}{l}\text { FGHR } \\
\text { from hot } \\
\text { stoves }\end{array}$ & $\begin{array}{l}\text { Coke dry } \\
\text { quenching } \\
\text { (CDQ) }\end{array}$ & $\begin{array}{l}\text { Dry slag } \\
\text { granulation } \\
(\mathrm{DSG})\end{array}$ & $\begin{array}{l}\text { Biomass- } \\
\text { fired CHP } \\
\text { (Bio-CHP) }\end{array}$ \\
\hline First introduced in & HL1 & HL2 & HL3 & HL4 & HL5 & HL6 \\
\hline $\begin{array}{l}\text { Steam piping } \\
\text { velocity } 30 \mathrm{~m} / \mathrm{s}\end{array}$ & 50 & 100 & $700 / 50$ & 3000 & 100 & 100 \\
\hline Equipment & & & & & & \\
\hline Steam boiler & - & $\checkmark$ & $\checkmark$ & n.a. & $\checkmark$ & n.a. \\
\hline Condenser/cooler & - & $\checkmark$ & $\checkmark$ & n.a. & $\checkmark$ & n.a. \\
\hline Condensate pump & - & $\checkmark$ & $\checkmark$ & n.a. & $\sqrt{ }$ & n.a. \\
\hline Condensate tank & - & $\checkmark$ & $\checkmark$ & n.a. & $\checkmark$ & n.a. \\
\hline Air fan & - & $\checkmark$ & - & n.a. & - & n.a. \\
\hline Flare gas piping $(\mathrm{m})$ & & 200 & & & & \\
\hline Special equipment & - & - & - & CDQ plant $^{1}$ & DSG plant $^{2}$ & CHP plant $^{3}$ \\
\hline Scaling size & - & - & - & 100 & 300 & 132 \\
\hline Unit & & & & $\mathrm{t}$ coke/h & kt slag/yr & MWth \\
\hline Cost $\left(\mathrm{k} €_{2015}\right)$ & - & - & - & 40,250 & 8,057 & 80,000 \\
\hline Reference & - & - & - & 4 & 5 & 6 \\
\hline
\end{tabular}

838 n.a., Does not apply/considered in special equipment.

$839{ }^{1} \mathrm{CDQ}$ : cooling vessel, recovery boiler, gas circulation system, steam cycle.

840 2DSG: dry granulator, moving bed heat exchanger, blower, off-gas system.

$841{ }^{3}$ Bio-CHP plant: back-pressure turbine, steam cycle with biomass boiler.

$842{ }^{4}($ SSAB EMEA AB, 2012)

8435 (Norgate et al., 2012; U.S. DOE Energy Efficiency \& Renewable Energy, 2016)

$844 \quad{ }^{6}$ (Haaker, 2007) 
Manuscript - Excess Heat-Driven Carbon Capture at an Integrated Steel Mill Considerations for Capture Cost Optimization

846 A.1.3 Net abatement cost and carbon price projections

847 The net abatement cost is calculated (cf. Eq. (3)) for three carbon price projections for the period

848 2020-2040: 1) a sustainable development scenario in line with the $2^{\circ} \mathrm{C}$ target (WEO $\left.2^{\circ} \mathrm{C}\right) ; 2$ )

849 an adapted moderate development scenario by NEPP (WEO \& NEPP); and 3) a market-oriented

850 EUA forecast (EU ETS forecast). For the same time period, the electricity price projection for

851 Sweden is taken from the latest results of the NEPP project. The underlying price assumptions

852 are listed in Table A.3.

853 Table A.3: Carbon prices $\left(\mathrm{CO}_{2}\right)$ and Swedish electricity price scenarios for the period 2020-2040

\begin{tabular}{|c|c|c|c|c|}
\hline \multirow[t]{2}{*}{ Year } & \multicolumn{3}{|c|}{$\begin{array}{c}\text { Carbon price } \\
€_{2015} / \mathrm{t} \mathrm{CO}_{2}\end{array}$} & \begin{tabular}{|l} 
Electricity price \\
$€_{2015} / \mathrm{MWh}$ \\
\end{tabular} \\
\hline & WEO \& NEPP & WEO $2^{\circ} \mathrm{C}$ & EU ETS forecast & \\
\hline 2018 & 17.7 & 17.7 & 17.7 & 41.6 \\
\hline 2020 & 24.1 & 28.4 & 23.7 & 42.4 \\
\hline 2025 & 40.0 & 55.1 & 21.5 & 44.5 \\
\hline 2030 & 60.0 & 77.5 & 25.3 & 45.6 \\
\hline 2035 & 91.2 & 100.0 & $33.6^{1}$ & 50.5 \\
\hline 2040 & 122.4 & 122.4 & $42.2^{1}$ & 54.2 \\
\hline source & $\begin{array}{r}\text { (IEA, 2018; } \\
\text { NEPP, 2019) }\end{array}$ & (IEA, 2018) & (Qin, 2018) & (Rydén and Unger, 2018) \\
\hline
\end{tabular}

$854{ }^{1}$ Extrapolated values from estimated prices for period 2026-2030.

855

856 


\section{Manuscript - Excess Heat-Driven Carbon Capture at an Integrated Steel Mill - Considerations for Capture Cost Optimization}

Table A.4: Capital expenditures in $\mathrm{k}_{2015}$ (thousands) of the capture plants for two scenarios: partial capture from

859 BFG with excess heat (S2 HL3), and full capture from BFG, hot stoves and CHP plant (S5 HL5). The 'ID'

860 corresponds to equipment in Figure A1, '\#' stands for quantity of each equipment, 'size' for the aggregated size

861 of an equipment type except for vessels, where '/ denotes the ratio between height and diameter.

\begin{tabular}{|c|c|c|c|c|c|c|c|c|c|c|}
\hline \multirow[b]{2}{*}{ Equipment } & \multirow[b]{2}{*}{ ID } & \multirow[b]{2}{*}{ type } & \multicolumn{4}{|c|}{ Partial capture S2 HL3 } & \multicolumn{4}{|c|}{ Full capture S5 HL6 } \\
\hline & & & \# & size & & cost $\mathrm{k} €$ & \# & siz & & cost $\mathrm{k} €$ \\
\hline \multicolumn{11}{|l|}{ Rotary } \\
\hline Rich solvent pump & P-RICH & Centrifugal & 1 & 21 & $\mathrm{~kW}$ & 410 & 3 & 130 & $\mathrm{~kW}$ & 2330 \\
\hline $\mathrm{CO} 2$ pump & $\mathrm{P}-\mathrm{CO} 2$ & Centrifugal & 1 & 250 & $\mathrm{~kW}$ & 990 & 2 & 550 & $\mathrm{~kW}$ & 2890 \\
\hline MEA make-up pump & OP-1 & Centrifugal & 1 & $>0$ & $\mathrm{~kW}$ & 20 & 2 & $>0$ & $\mathrm{~kW}$ & 30 \\
\hline Make-up water pump & OP-2 & Centrifugal & 1 & 0 & $\mathrm{~kW}$ & 30 & 2 & 3 & $\mathrm{~kW}$ & 70 \\
\hline Absorber buffer pump & OP-3 & Centrifugal & 1 & 40 & $\mathrm{~kW}$ & 150 & 2 & 80 & $\mathrm{~kW}$ & 340 \\
\hline Lean solvent pump & P-LEAN & Centrifugal & 1 & 300 & $\mathrm{~kW}$ & 1210 & 2 & 710 & $\mathrm{~kW}$ & 2630 \\
\hline Stripper buffer pump & OP-4 & Centrifugal & 1 & 30 & $\mathrm{~kW}$ & 190 & 2 & 70 & $\mathrm{~kW}$ & 500 \\
\hline Stripper reflux pump & P-RFLX & Centrifugal & 1 & 1 & $\mathrm{~kW}$ & 60 & 2 & 10 & $\mathrm{~kW}$ & 150 \\
\hline Cooling water pump & $\mathrm{P}-\mathrm{CW}$ & Centrifugal & 1 & 850 & $\mathrm{~kW}$ & 4800 & 2 & 2080 & $\mathrm{~kW}$ & 10640 \\
\hline Intercooler pump & OP-5 & Centrifugal & 1 & 70 & $\mathrm{~kW}$ & 190 & 3 & 150 & $\mathrm{~kW}$ & 1940 \\
\hline DCC circulation pump & P-DCC & Centrifugal & 1 & - & $\mathrm{kW}$ & - & 2 & 200 & $\mathrm{~kW}$ & 880 \\
\hline Flue gas fan & FAN-1 & Blower & 1 & 360 & $\mathrm{~kW}$ & 570 & 3 & 810 & $\mathrm{~kW}$ & 1480 \\
\hline Four-stage compressor & $\begin{array}{l}\text { COMP-1 - } \\
\text { COMP-4 }\end{array}$ & Centrifugal & 1 & 12540 & $\mathrm{~kW}$ & 35790 & 2 & 31410 & $\mathrm{~kW}$ & 76750 \\
\hline \multicolumn{11}{|l|}{ Vessels } \\
\hline Absorber column & ABS-1 & SS316 & 1 & $22 / 8$ & $\mathrm{~m}$ & 5600 & 3 & - & $\mathrm{m}$ & 11930 \\
\hline Absorber packing & Sulzer Mella & oak $250 \mathrm{Y}$ & 1 & $15 / 8$ & $\mathrm{~m}$ & 3220 & 3 & - & $\mathrm{m}$ & 19250 \\
\hline Stripper column & STR-1 & SS316 & 1 & $28 / 7$ & $\mathrm{~m}$ & 3380 & 2 & - & $\mathrm{m}$ & 7470 \\
\hline Stripper packing & Sulzer Mella & oak $250 \mathrm{Y}$ & 1 & $20 / 7$ & $\mathrm{~m}$ & 1600 & 2 & - & $\mathrm{m}$ & 10730 \\
\hline Washer column & WASH-1 & SS316 & 1 & $2 / 8$ & $\mathrm{~m}$ & 2380 & 3 & - & $\mathrm{m}$ & 6790 \\
\hline Washer packing & Sulzer Mella & oak $250 \mathrm{Y}$ & 1 & $1.4 / 8$ & $\mathrm{~m}$ & 780 & 3 & - & $\mathrm{m}$ & 6968 \\
\hline MEA make-up tank & TANK-1 & SS316 & 1 & 10 & $\mathrm{~m}^{3}$ & 300 & 2 & - & $\mathrm{m}^{3}$ & 680 \\
\hline Absorber buffer tank & TANK-2 & SS316 & 1 & 10 & $\mathrm{~m}^{3}$ & 290 & 2 & - & $\mathrm{m}^{3}$ & 680 \\
\hline Stripper buffer tank & TANK-3 & SS316 & 1 & 10 & $\mathrm{~m}^{3}$ & 340 & 2 & - & $\mathrm{m}^{3}$ & 680 \\
\hline DCC column & DCC & SS316 & 0 & - & $\mathrm{m}$ & - & 2 & - & $\mathrm{m}$ & 5080 \\
\hline DCC packing & Sulzer Mella & oak $250 Y$ & 0 & - & $\mathrm{m}$ & - & 2 & - & $\mathrm{m}$ & 13576 \\
\hline Condenser KO drum & RFLX & SS316 & 1 & $6 / 4$ & $\mathrm{~m}$ & 1400 & 2 & - & $\mathrm{m}$ & 2370 \\
\hline Knock-out drum & & SS316 & 4 & $5 / 3$ & $\mathrm{~m}$ & 2480 & 8 & - & $\mathrm{m}$ & 5850 \\
\hline \multicolumn{11}{|l|}{ Heat exchangers } \\
\hline DCC circulation cooler & HX-DCC & Shell\& & 0 & - & $\mathrm{m}^{2}$ & - & 3 & 2220 & $\mathrm{~m}^{2}$ & 2360 \\
\hline Cross heat exchanger & HX-ECO & Shell\&Tube & 17 & 16,000 & $\mathrm{~m}^{2}$ & 16730 & 32 & 32680 & $\mathrm{~m}^{2}$ & 32070 \\
\hline Stripper condenser & COND & Shell\&Tube & 1 & 510 & $\mathrm{~m}^{2}$ & 650 & 3 & 2580 & $\mathrm{~m}^{2}$ & 2360 \\
\hline Stripper reboiler & REB & Thermosyphon & 13 & 12,290 & $\mathrm{~m}^{2}$ & 13910 & 32 & 30840 & $\mathrm{~m}^{2}$ & 26920 \\
\hline Lean solvent cooler & HX-LEAN & Shell\&Tube & 3 & 2,720 & $\mathrm{~m}^{2}$ & 2660 & 5 & 3870 & $\mathrm{~m}^{2}$ & 3860 \\
\hline Absorber intercooler & HX-ABS & Shell\&Tube & 2 & 1,130 & $\mathrm{~m}^{2}$ & 1360 & 5 & 4290 & $\mathrm{~m}^{2}$ & 3770 \\
\hline Intercooler 1 & $\mathrm{HX}-1$ & Shell\&Tube & 1 & 460 & $\mathrm{~m}^{2}$ & 610 & 2 & 990 & $\mathrm{~m}^{2}$ & 1580 \\
\hline Intercooler 2 & HX-2 & Shell\&Tube & 1 & 460 & $\mathrm{~m}^{2}$ & 670 & 2 & 990 & $\mathrm{~m}^{2}$ & 2420 \\
\hline Intercooler 3 & $\mathrm{HX}-3$ & Shell\&Tube & 1 & 520 & $\mathrm{~m}^{2}$ & 930 & 2 & 1110 & $\mathrm{~m}^{2}$ & 1630 \\
\hline Intercooler 4 & HX-4 & Shell\&Tube & 2 & 1,440 & $\mathrm{~m}^{2}$ & 3880 & 4 & 3080 & $\mathrm{~m}^{2}$ & 5570 \\
\hline \multicolumn{11}{|l|}{ Other } \\
\hline Pre and pos & & & 2 & - & & 260 & 4 & - & & 520 \\
\hline Active carbon filter & & & 1 & - & & 240 & 2 & - & & 480 \\
\hline Gas piping column & & SS316 & 1 & 100 & $\mathrm{~m}$ & 6920 & 2 & 230 & $\mathrm{~m}$ & 30940 \\
\hline Total installatic & & & & & & 115000 & & & & 307160 \\
\hline
\end{tabular}


Manuscript - Excess Heat-Driven Carbon Capture at an Integrated Steel Mill - Considerations for Capture Cost Optimization

\section{A.3 Comparison with data from the literature}

Table A.5: Comparisonsof the data in the literature for absorption of $\mathrm{CO}_{2}$ using 30 wt.\% aqueous MEA solvent.

\begin{tabular}{|c|c|c|c|c|c|c|c|c|c|c|}
\hline Study & & Arasto/Tsupari & \multicolumn{2}{|c|}{ IEAGHG } & Cormos & \multicolumn{2}{|l|}{ Ho } & Kuramochi & Kim & Dreillard \\
\hline Site & & $\begin{array}{c}\text { Raahe Steel Mill, } \\
\text { FI }\end{array}$ & \multicolumn{3}{|c|}{ conceptual western Europe } & \multicolumn{2}{|c|}{ Ijmuiden, NL } & n.a. & n.a., $\mathrm{KR}$ & $\begin{array}{l}\text { IFPEN mini } \\
\text { pilot, FR }\end{array}$ \\
\hline Site characteristic & & $\begin{array}{l}\text { existing, district } \\
\text { heating }\end{array}$ & \multicolumn{3}{|c|}{$\begin{array}{l}\text { greenfield, access to Rotterdam; no export of } \\
\text { energy (no district heating) }\end{array}$} & \multicolumn{2}{|c|}{$\begin{array}{l}\text { integrated site; district } \\
\text { heating }\end{array}$} & integrated & integrated & $\begin{array}{l}\text { Arcelor } \\
\text { Mittal data }\end{array}$ \\
\hline $\mathrm{CO}_{2}$ source & & $\mathrm{HS}+\mathrm{CHP}$ & $\mathrm{HS}+\mathrm{CHP}$ & $\begin{array}{l}\mathrm{HS}+\mathrm{CHP}+ \\
\text { coke ovens }\end{array}$ & $\begin{array}{c}\text { HS + CHP + } \\
\text { coke ovens + } \\
\text { lime kiln }\end{array}$ & $\begin{array}{c}\text { HS + CHP } \\
+ \text { coke ovens } \\
+ \text { sinter }\end{array}$ & BFG & BFG & BFG & BFG \\
\hline Capture rate $\left(\mathrm{CO}_{2}\right.$ source $)$ & $\%$ & 90 & 90 & 90 & 90 & 90 & 90 & n.a. & 90 & 90 \\
\hline Capture rate (site) & $\%$ & $50-75$ & 50 & 60 & $50-60$ & 80 & 30 & 19 & n.a. & n.a. \\
\hline Scale & $\mathrm{Mt} \mathrm{CO} / \mathrm{a}$ & $2-3$ & 5.0 & 6.1 & $5-6.5$ & 8 & 3.2 & 1.3 & 0.7 & n.a. \\
\hline \multicolumn{2}{|l|}{ Heat source } & $\begin{array}{l}\text { power plant } \\
\text { renewal; off- } \\
\text { gases }\end{array}$ & \multicolumn{2}{|c|}{$\begin{array}{l}\text { CHP plant fired with NG, } \\
\text { BFG, BOFG }\end{array}$} & $\begin{array}{l}\text { NGCC power } \\
\text { plant }\end{array}$ & \multicolumn{2}{|c|}{$\begin{array}{c}\text { CHP plant fired with NG, } \\
\text { BFG, BOFG }\end{array}$} & n.a. & $\begin{array}{l}\text { CHP fueled } \\
\text { by off-gas } \\
\text { only }\end{array}$ & $\begin{array}{l}\text { external } \\
\text { steam }\end{array}$ \\
\hline Specific heat demand & $\mathrm{MJ} / \mathrm{kg} \mathrm{CO} 2$ & 3.40 & 3.03 & $3.03 / 3.18$ & 2.95 & n.a. & n.a. & 4.40 & n.a. & $3.3-3.6$ \\
\hline $\mathrm{CO}_{2}$ compression & bar & 60 & 110 & 110 & 120 & 100 & 100 & 110 & 150 & 6 \\
\hline Cost year & & 2012 & 2010 & 2010 & 2016 & 2010 & 2010 & 2007 & 2011 & 2018 \\
\hline Rate of return & $\%$ & 10 & 10 & 10 & n.a. & n.a. & n.a. & 10 & 8 & n.a. \\
\hline Life time & years & 20 & 25 & 25 & n.a. & 25 & 25 & 20 & 20 & n.a. \\
\hline Cost avoided & $\begin{array}{r}\text { [currency]// } \\
\text { tonne } \mathrm{CO}_{2}\end{array}$ & $\begin{array}{r}84-114^{1} \\
\text { [EUR] }\end{array}$ & $\begin{array}{r}74 \\
\text { [USD] }\end{array}$ & $\begin{array}{r}81 \\
\text { [USD] }\end{array}$ & $\begin{array}{r}100-150 \\
{[E U R]}\end{array}$ & $\begin{array}{r}80 \text { (75-96) } \\
{[\text { AUD] }} \\
\end{array}$ & $\begin{array}{r}76 \\
\text { [AUD] }\end{array}$ & $\begin{array}{r}64 \\
\text { [EUR] } \\
\end{array}$ & $\begin{array}{r}71.7 \\
\text { [USD] }\end{array}$ & $\begin{array}{r}63.6 \\
\text { [EUR] }\end{array}$ \\
\hline Cost avoided - levelized & $\begin{array}{r}€ 2015 / \\
\text { tonne } \mathrm{CO}_{2} \\
\text { avoided } \\
\end{array}$ & $86-116^{1}$ & 60 & 66 & $100-150$ & $60(56-72)$ & 57 & 72 & 54 & 62 \\
\hline Reference & & $\begin{array}{c}\text { (Arasto et al., } \\
\text { 2013; Tsupari et } \\
\text { al., 2013) }\end{array}$ & \multicolumn{2}{|c|}{ (IEAGHG, 2013) } & $\begin{array}{l}\text { (Cormos, } \\
\text { 2016) }\end{array}$ & \multicolumn{2}{|c|}{ (Ho et al., 2013) } & $\begin{array}{l}\text { (Kuramochi } \\
\text { et al., 2012) }\end{array}$ & $\begin{array}{l}\text { (Kim et al., } \\
2015)\end{array}$ & $\begin{array}{l}\text { (Dreillard et } \\
\text { al., 2017) }\end{array}$ \\
\hline
\end{tabular}


Manuscript - Excess Heat-Driven Carbon Capture at an Integrated Steel Mill Considerations for Capture Cost Optimization

867 